\title{
Erosional processes and paleo-environmental changes in the Western Gulf of Lions (SW France) during the Messinian Salinity Crisis
}

\author{
Johanna Lofi ${ }^{a, b^{*}}$, Christian Gorini ${ }^{c}$, Serge Berné ${ }^{b}$, Georges Clauzon $^{d}$, A. Tadeu Dos Reis ${ }^{e}$, \\ William B.F. Ryan ${ }^{\mathrm{f}}$ and Michael S. Steckler ${ }^{\mathrm{f}}$
}

\author{
aIFREMER, DRO/GM Technopôle Brest-Iroise, B.P. 70, 29280 Plouzané, France \\ ${ }^{\mathrm{b}}$ Cefrem, Université de perpignan, 52, avenue de Villeneuv, 66860 PERPIGNAN Cedex, France. \\ 'Université de Lille 1, SN5 F, 59655 Villeneuve d'Ascq Cedex, France \\ ${ }^{d}$ CEREGE, Europôle de l'Arbois, 13545 Aix-en-Provence Cédex 04, France \\ e Department of Oceanography-UERJ, Rua Sao Franciso Xavier, 524, Rio de Janeiro/RJ, CEP20550-090, Brazil \\ fLamont-Doherty Earth Observatory, Palisades, NY 10964, USA
}

*: Corresponding author : Present address: Cefrem, Université de perpignan, 52, avenue de Velleneuve, 66860 PERPIGNAN Cedex, France. Tel.: +33 4686620 91. johanna.lofi@univ-perp.fr

\begin{abstract}
Current interpretation of the Messinian Salinity Crisis (MSC) involves partial "desiccation" of the Mediterranean Sea coupled with the deposition of thick evaporites in the deep basins. New sets of seismic reflection profiles in the western part of the Gulf of Lions confirm the basinward extension of the Messinian erosion and enable the mapping of distinctive seismic markers indicating the Messinian Erosional Surface (or Messinian unconformity), the basin-margin detrital deposits, and the deep evaporite sequence. The geometrical relationship between these three elements and their relationship to the paleogeography of the margin during the MSC provide new information about the evolution of the study area during the Messinian.

The Messinian Erosional Surface (MES), commonly correlated with the "desiccation" phase and the deposition of deep evaporites during the apogee of the event, is generally interpreted as a subaerial feature. In the Gulf of Lions, it is a complex diachronic polygenic erosional surface observed at the base of the prograding Plio-Quaternary sequence beneath the shelf and slope; it extends downslope beneath the deep basin Upper Evaporites and the Salt, and possibly correlates conformably with the base of the so-called deep Lower Evaporites. The whole morphology of the MES reflects a buried drainage pattern, supporting the interpretation of fluvial erosion driven by a substantial drop in sea level. Our results also suggest that large submarine gravity flows occurred prior to any significant accumulation of Salt in the basin and prior to the Upper Evaporites. Consequently, interbedded clastic deposits may partly account for the parallel reflectors of the Lower Evaporites. Since river erosion persisted throughout the MSC, the Salt and Upper Evaporite units may also contain a large amount of detrital sediments.

The good quality of the new seismic data clearly reveals fan-shaped Messinian deposits in the downstream part of the main Messinian valleys (i.e., the Nile, Var, and Spanish rivers). The depositional scenarios generally involve a substantial sea-level fall coupled with deltaic/prodeltaic accumulations. A chaotic seismic unit (Unit D) filling Messinian lows and extending beneath the Salt within the study area is interpreted as a Messinian clastic unit. We propose a polyphase scenario of detrital fan deposition involving pre-, syn-, and post-Salt deposition in subaqueous/subaerial environments.

In the Gulf of Lions, a late Miocene tectonic phase that affected the western shelf also played an important role in controlling (a) the pattern of the Messinian fluvial network, (b) the location of maximum erosion on the shelf, and (c) the location of the detrital fan depocentre downslope.
\end{abstract}

Keywords: Gulf of Lions; Messinian Salinity Crisis; erosional surface; detrital deposits; tectonism; eustasy; fluvial erosion 


\section{Introduction}

During the Late Miocene, the Mediterranean area underwent rapid and dramatic paleoenvironmental changes known as the "Messinian Salinity Crisis" (Hsü et al., 1973): an event characterised by the deposition of thick evaporites in both the shallow (peripheral) and deep Mediterranean basins. Many debates concerning the causes and modalities of this event have animated the scientific community since 1970. At present, it is the "deep-desiccated basin model” (Hsü et al., 1973) that is generally accepted to explain the partial "desiccation" of the Mediterranean Sea associated with a huge sea-level fall (at least $1500 \mathrm{~m}$ ). Nevertheless, several points are still under debate, such as a) the detailed chronology of the Messinian Salinity Crisis (Clauzon et al., 1996; Krijgsman et al., 1999a); b) some of the factors triggering this event, such as global sea-level fall (Kastens, 1992); c) the stratigraphic position of some peripheral deposits (Riding et al., 1998, 2000; Fortuin et al., 2000); d) the time taken to refill the Mediterranean Basin at the end of the crisis (Clauzon et al., 1996; Krijgsman et al., 1999a; Blanc, 2002); and e) the origin and significance of the Lago Mare deposits (Hsü et al., 1973; Rouchy and Saint Martin, 1992; Orszag-Sperber et al., 2000; Clauzon and Suc, 2002). In addition, the amplitude of the sea-level fall and the in situ character of the evaporites above the abyssal plains have been recently thrown back into the debate by some authors (Roveri et al., 2001).

The Messinian Salinity Crisis started at about 5.96 Ma (Gautier et al., 1994; Krijgsman et al., 1999a) with the Tortonian to Late Messinian tectonic uplift of the Gibraltar Strait resulting in progressive closure of the two-way connection between the Atlantic Ocean and the Mediterranean Sea (Benson et al., 1991; Krijgsman et al., 1999b). Based on geochemical analyses of volcanic rocks from the western Mediterranean, however, Duggen et al. (2003) suggest that the progressive closure (and re-opening) of the waterways would more likely be the result of a significant change in the geodynamic and mantle evolution of the region. At this point, the combined effect of a global sea-level fall is still under discussion (Clauzon et al., 1996; Krijgsman et al., 1999a).

Restricted communication with the Atlantic Ocean (Seidenkrantz et al., 2000) led to a gradual increase in water salinity, this being favoured by the already existing xero-thermic climate of the Mediterranean (Suc and Bessais, 1990). This was followed at about 5.6 Ma (Clauzon et al., 1996; Krijgsman et al., 1999a) by a dramatic fall in the sea level of the Mediterranean Basin (Ryan, 1976; Clauzon, 1982) and the deposition of evaporites up to $1400 \mathrm{~m}$ thick in the deep basins (Montadert et al., 1970). Evidence for the substantial drop in sea level has been collected from numerous records of deep erosional features in marginal areas. Moreover, a widespread erosional surface known as the "Messinian Erosional Surface" (MES) is visible both on seismic reflection profiles and in outcrop, and has been observed and studied in several Mediterranean margins (Ryan and Cita, 1978). This unconformity is commonly interpreted as the product of subaerial erosion, essentially by river action, during the apogee of the Messinian Salinity Crisis (Rizzini et al., 1978; Ryan and Cita, 1978; Barber, 1981; Stampfli and Höcker, 1989; Field and Gardner, 1991; Escutia and Maldonado, 1992). Onshore, the MES is characterised by the presence of deep narrow incisions, or "canyons", which correspond to the entrenchment of streams in response to the huge fall in sea level (Chumakov, 1973; Clauzon, 1973; Clauzon, 1982). Offshore, numerous investigations have enabled a reconstruction of the detailed paleo-morphologies of the MES at several margins, revealing the existence of Messinian paleo-fluvial networks such as on the Egyptian margin (Barber, 1981), the Gulf of Lions shelf (Gennesseaux and Lefebvre, 1980; Guennoc et al., 2000) and the Ebro margin and Valencia trough (Stampfli and Höcker, 1989). Subaerial erosional features (e.g. desiccation cracks and stromatolite layering [DSDP, Leg 42], fossil meanders and fluvial terraces [Stampfli and Höcker, 1989]) have also been described from 
margin edges of the deep basins, thus supporting the interpretation of fluvial erosion driven by a substantial sea-level fall. In addition, sands and conglomerates overlain by Early Pliocene deep-marine sediments have been sampled in Messinian thalwegs. These are interpreted as Messinian fluvio-deltaic deposits resulting from the erosion of the margins during the MSC (Rizzini et al., 1978; Estocade, 1978; Stampfli and Höcker, 1989; Savoye and Piper, 1991).

Most studies concerning the MSC in the Gulf of Lions (Fig. 1) have focused either on detailed analyses of oil wells (Cravatte et al., 1974; Suc and Drivaliari, 1991; Fauquette et al., 1999) and onshore outcrops (Clauzon, 1978; Ambert et al., 1998), or on seismic interpretation of the MES beneath the shelf (Gennesseaux and Lefebvre, 1980; Guennoc et al., 2000). With new sets of seismic data acquired by TotalFinaElf (TFE) and Ifremer, it is now possible to investigate distinct seismic markers of the MSC across the entire margin from the inner shelf area down to the basin.

In the present study, we carried out seismic interpretation and mapping essentially in the Languedoc-Roussillon area in the western half of the margin. Our aim has been a detailed documentation of the spatial and temporal relationships between the MES, the associated basin-margin deposits, and the evaporite sequence in the deep basin. We discuss the factors controlling the MES morphology, the amount of sediment eroded from the margin during the MSC, and the fate of the eroded sediments. We then propose a reconstruction of the paleoenvironmental evolution of the study area during this event.

\section{Geological setting}

The Gulf of Lions continental margin forms the western part of the Provençal Basin, which resulted from a short Oligo-Aquitanian rifting event that separated the Corsica-Sardinia microplate from continental Europe (Le Pichon et al., 1971; Réhault et al., 1984). The rifting itself occurred between 30 and $24 \mathrm{Ma}$ and produced a series of tectonic grabens in the Gulf of Lions. A distinct syn-rift sequence of sandy shales is locally visible on the seismic sections, overlain by a thick post-rift sequence dominated by clastic sedimentation (Gorini et al., 1993). Recent studies in the western domain of the margin have revealed that the Miocene sequence is offset by a number of normal Late Miocene faults (Fig. 2) associated with an extensional phase dated from the latest Miocene - Early Pliocene (Mauffret et al., 2001). This event led to a tilting of the Miocene sedimentary cover and the creation of a rollover structure (Rascasse rollover, Fig. 2, A), whose axis is in the offshore continuation of Cap Creus, on the southwestern outer shelf area (Fig. 2, D). Most of the observed faults are sealed by the Messinian unconformity and do not appear to be associated with pre-Tertiary basement structures (Gorini et al., in press). The cause of this extensional phase has yet to be clarified and may be linked to uplift in the eastern Pyrenees. Gorini et al. (2003, in press) suggest that this Late Miocene extension may, in fact, result from a gravity-driven destabilisation of the shelf, associated with an isostatic rebound due to the base-level lowering and the increase in seawater density in the deep basin during the MSC. The tilting of the margin would then be a direct consequence of the MSC event.

The post-rift sedimentation in the Gulf of Lions was also strongly influenced by the MSC. In the deep basin, the post-rift deposits include an evaporite sequence that correlates landward with the MES (Montadert et al., 1970). Over the shelf, the post-Messinian sequence consists of a thick Plio-Quaternary succession whose deposition began in the Early Pliocene and led to a progradation of the Gulf of Lions margin by as much as $120 \mathrm{~km}$ (Lofi et al., 2003a). Up to $2000 \mathrm{~m}$ of Plio-Quaternary sediment covers the Messinian unconformity beneath the outer shelf. 
Detailed mapping of the morphology of the MES beneath the Gulf of Lions shelf by Gennesseaux and Lefebvre (1980), and more recently by Guennoc et al. (2000), has revealed the existence of two main subaerial Messinian valleys: the Rhône valley system to the east, and the Languedoc-Roussillon valley system to the west. The present study was focused on the Languedoc-Roussillon network, which covers the western part of the Gulf of Lions shelf. The MES in this sector is a widespread surface with significant relief beneath the inner shelf; its extension beneath the present-day slope has still to be accurately mapped.

The Gulf of Lions margin only displays a widespread MES associated with the evaporite sequence in the deep basin; it does not contain the peripheral successions of uncertain age in relation to the MSC and the "desiccation" phase that have been reported elsewhere (Clauzon et al., 1996; Riding et al., 1998; Krijgsman et al., 1999a). In this study, therefore, we can adopt the chronostratigraphic scheme proposed either by Clauzon et al. (1996) or by Krijgsman et al. (1999a) to date the beginning of the MES formation at around 5.6 Ma (Fig. $3)$. The end of the MES formation and the rapidity with which the Mediterranean Basin was refilled at the end of the MSC - between a few thousand years (Clauzon et al., 1996) and about 200,000 years (Krijgsman et al., 1999a) — are discussed later.

\section{Methods and data}

\subsection{Seismic data}

Some of the geophysical data used in this work, such as the high-quality LRM96 (Languedoc-Roussillon-Maritime 96) profiles covering the western part of the shelf from Cap Creus in the southwest up to Cap Agde in the northeast (Fig. 1), have been acquired by ELF since 1996. Unfortunately we did not have the digital data. Moreover, as the seismic lines were "cut" beneath the MES, we did not have records for the pre-Messinian deposits (apart from in a few lines, Fig. 2). Additional multi-channel profiles (ACHERE) were acquired on the slope in the eastern part of the study area, and a second set of geophysical data consisting of high-resolution multi-channel profiles was acquired by Ifremer in 1997 and 2001 during the CALMAR (CAtalano-Languedocian MARgin; Berné et al., 1999) and MARION (MARgin of Gulf of LIONs) cruises. These lines cover the slope and the rise of the study area (Fig. 1), linking the continental shelf and the basin plain.

Analysis of the data in terms of reflector terminations (erosional truncations and downlaps) and configurations has revealed an acoustic basement that we interpret as the MES beneath the present-day shelf and slope. The seismic profiles have also made it possible to precisely identify the Messinian valleys and their thalwegs, and so map the Messinian drainage networks beneath the present-day shelf and slope. Onshore, the Messinian networks have been traced from outcrops, boreholes and literature data.

\subsection{Exploration wells, stratigraphic correlation and time-depth conversions}

Data from nine exploration wells are available within the study area. Six of these are located on the inner and middle shelf, Autan 1 was drilled on the shelf edge, and GLP1 and GLP2 were drilled at the continental slope (see Fig. 1 for location). The MES was tied in to these wells using time-depth conversions (see below). Despite the lack of biostratigraphic descriptions for some of the wells, the drilling reports and the work of Cravatte et al. (1974) clearly reveal the presence of the MES and its Messinian age.

The time-depth conversions used for the seismic reflectors and borehole data were based on the velocity relationship proposed by Lofi et al. (2003a) for the Plio-Quaternary sequence. 
To compute an isopach map of Unit D (see Section 4.3 for the description of this unit) from the travel time, we imposed a uniform $1500 \mathrm{~m} / \mathrm{sec}$ for the velocity of sound in water and a uniform $2500 \mathrm{~m} / \mathrm{sec}$ for the velocity of sound in the deposits.

\subsection{Estimation of the sediment volume eroded from the shelf}

The Miocene seismic reflectors beneath the Gulf of Lions shelf are roughly parallel to one another and are offset by a number of normal Late Miocene faults (Fig. 2). In view of this, we used the methodology proposed by Mauffret et al. (2001) to estimate the amount of sediment eroded from the shelf during the MSC. Using the LRM96 profiles, we searched for the youngest Miocene reflector visible just below the MES (Fig. 4A). Because this reflector is preserved only locally, we established its original lateral extension by drawing a ghost line passing through the reflector and running parallel to an older Miocene reflector observable throughout the study area. We decreased the parallelism landward to allow for the progressive tilt of the margin with time. We then estimated the volume between our ghost horizon and the MES using a constant velocity of $2000 \mathrm{~m} / \mathrm{sec}$ for the corresponding deposits.

The major problem encountered in estimating the volume of sediment eroded during the MSC is that, due to the MES, we have little evidence with which to reconstruct the morphology of the pre-crisis margin. We consequently assumed that: 1) the traced ghost of the youngest Miocene reflector reflects a rough morphology of the Miocene shelf at the beginning of the MSC; 2) this ghost reflector was not eroded until after the tilting of the shelf associated with the Late Miocene extensional phase (should this not be the case, then our budget is overestimated); and 3) the ghost reflector was not overlain by a large amount of sediment before the beginning of the MSC (should this not be the case, then our budget is underestimated).

Despite the lack of stratigraphic control and the assumptions described above (plus the fact that sediment compaction within the eroded interval is not taken into account), the method has for the first time enabled a rough estimate of the volume of sediment eroded from a shelf during the crisis. The calculation does not, however, take into account either the volume of sediment eroded from the canyons onshore, nor the volume of sediment eroded from the Miocene slope (Fig. 4B). Consequently, it only accounts for part of the total volume eroded from the Languedoc-Roussillon margin during the crisis.

\section{Results}

\subsection{The Messinian evaporite sequence}

Seismic profile analysis has enabled identification of the classic deep Messinian evaporite sequence in the basin and beneath the lower slope. Based on previous work in the Gulf of Lions (Dos Reis, 2001; Dos Reis et al., in press), the following downward succession is recognised at the base of the Plio-Quaternary sequence (Fig. 5):

- the Upper Evaporite unit, at the top, indicated by a group of parallel and relatively continuous reflectors. The top of this unit correlates with a prominent seismic reflector usually referred to as the " $M$ " reflector (Ryan et al., 1973). This Upper Evaporite unit was tied in to well GLP2 (Fig. 1) by Dos Reis (2001) where it comprises $300 \mathrm{~m}$ of interbedded salt, anhydrite and deep-water marl layers that are characteristic of the Upper Evaporites sequence sampled during DSDP leg XIII (Hsü et al., 1973). Overlying these deposits, but still beneath the Lower Pliocene clays, is a 50-m-thick unit of sandy clays intercalated with decimetre- to plurimetre-thick beds of azoic sandstone. In the upper 
$5 \mathrm{~m}$, the drilling report describes the occurrence of the acme of the Sphaeroidinellopsis subdehiscens biohorizon and the presence of few nodules of anhydrite at the base of the unit. Unfortunately, we lack more precise stratigraphic and lithological information for this transitional unit whose interpretation is crucial for understanding the paleoenvironmental changes that occurred during the deposition of the evaporite sequence in the deep basins. It is nevertheless worth noting the strong analogy between this transitional unit and the Abu Madi Formation drilled in the Nile and dated as Early Pliocene (Rizzini et al., 1978). The Abu Madi Formation comprises thick layers of sand interbedded with layers of clay containing foraminifera of the Sphaeroidinellopsis $s p$. zone (Rizzini et al., 1978); locally it is seen above the Rosetta Anhydrite Formation (Barber, 1981) interpreted as the landward equivalent of the deep basin Upper Evaporites.

- $\quad$ beneath the Upper Evaporites, the Messinian Salt unit on the basin floor corresponds to a transparent acoustic facies displaying plastic deformation. The top of the Salt unit correlates with the "K" reflector of Biju-Duval et al. (1978).

- beneath the Salt, a group of very continuous high-amplitude reflectors has been initially interpreted as the Lower Evaporites by analogy with the Lower Evaporites of the Sicilian peripheral basin. Based on this lithology, their thickness would range from 400 to $500 \mathrm{~m}$, but their nature and age are still unknown as they have never been drilled. The top of the supposed Lower Evaporites correlates with the "L" reflector identified by Montadert et al. (1970).

\subsection{The Messinian erosional surface (MES)}

\subsubsection{Seismic expression of the MES}

Our seismic records revealed a widespread erosional surface beneath the present-day shelf and slope (Fig. 6). This acoustic basement is interpreted as the MES, i.e. the discordant contact between the Miocene pre-MSC deposits and the overlying prograding Plio-Quaternary unit and/or syn-MSC detrital and deep evaporite deposits. The discordance has several distinct characteristics in the study area:

- the MES beneath the shelf corresponds to a prominent unconformity with a strong erosional character (Fig. 6). As indicated by the dip seismic LRM96 profiles, it is downlapped by Plio-Quaternary sediments that prograded over the shelf after the crisis (Lofi et al., 2003a). Locally, the faulted Miocene deposits are seen to be deeply truncated by the MES (Figs. 2 and 6A, shot number 700) and a high angular discordance between pre-Messinian and post-Messinian (Plio-Quaternary) deposits is commonly observed (see also Figs. 4 and 8 in Lofi et al., 2003a). The MES is extremely rugged, displaying high relief beneath the inner and middle shelf (Fig. 6A) but becoming smoother basinward as the angular discordance between the Miocene and Plio-Quaternary sequences decreases (Fig. 6B, shot numbers 1700 to 2700).

- the MES extends out beneath the present-day slope where it is markedly smoother compared to the inner and middle shelf areas (Figs. 7, 8 and 9). Locally, there is no obvious angular discordance between the Miocene and Plio-Quaternary sequences. In other places, the MES is shown either by downlaps of the Plio-Quaternary reflectors on the MES and/or by toplaps of underlying truncated reflectors (Fig. 7). A chaotic unit (Unit D) is observed locally at the base of the Plio-Quaternary sequence (Figs. 8 and 9); the MES can be traced beneath this seismic unit on the basis of local evidence of underlying truncated Miocene reflectors (Figs. 8B and 9). Figure 9 shows a strike seismic line acquired beneath the middle slope and illustrates the ' $\mathrm{V}$ ' morphology of the MES beneath Unit D. 
- $\quad$ the MES extends out downslope to a depth of at least $4.3 \mathrm{sec}$ TWTT (Fig. 10) where it has a clear erosional character. Both the Salt and the Upper Evaporite units pinch out against this surface beneath the lower continental slope. It is difficult to estimate how far the MES extends basinward because the surface progressively becomes conformable with the underlying strata. As suggested in Figure 10, the MES possibly correlates with the base of the Salt unit (reflector L). However, the Lower Evaporites display an unclear, but possible, onlap geometry landward suggesting that the MES could also be traced at the base of this unit (Fig. 10).

\subsubsection{Physiography of the MES}

The entire morphology of the MES beneath the shelf is one of an intricate drainage network with at least four orders of tributaries (Figs. 11 and 12). In the western part, the Languedoc-Roussillon network shows four distinct river patterns draining the northern, the north-western and western areas of the margin. They coalesce beneath the outer shelf to form a vast drainage channel located beneath the present-day head of the Aude (Bourcart) submarine canyon (Fig. 11). The Rhône, Orb-Hérault and Têt-Tech drainage systems connect respectively with the Messinian Rhône, Languedoc and Roussillon canyons observed onshore (Clauzon, 1973, 1982). Other systems, such as the Berre and proto-Aude, do not display upstream onshore canyons; they are incised entirely beneath the present-day shelf.

The seismic data have enabled us to trace the basinward prolongation of the LanguedocRoussillon paleo-network beneath the present-day slope. They have also enabled us to identify a new small network, the Rascasse network, in the southwestern extremity of the outer shelf and extending downslope on the southern flank of the Rascasse rollover (Figs. 11 and 12). This network drains a small area compared to the Languedoc-Roussillon network located to the north-east.

The Languedoc-Roussillon and Rascasse fluvial systems have now been mapped as follows. Beneath the present-day upper to middle slope, the networks form two isolated linear valleys running south-eastward (Fig. 11) and filled with a chaotic seismic unit (Unit D). Figure 9 illustrates the morphology of these systems in transverse section. The two Messinian valleys are separated by an interfluve of Miocene deposits that have been eroded and overlain by the downlapping Plio-Quaternary sediments (Figs. 7, 8 and 9). The Languedoc-Roussillon valley is deeply incised and the MES can be traced at the base of Unit D. The Rascasse valley is broader, less deeply incised, and the prolongation of the MES beneath Unit D is indistinct.

The Messinian valleys of the Gulf of Lions have irregular present-day longitudinal profiles reconstructed from seismic-reflection and onshore-borehole data. The gradient pattern is the same in each valley, with a flat-steep-flat-steep (Fig. 13A) or steep-flat-steep (Fig. 13B) profile; i.e. the steep slope sectors, ranging between 3 and $4 \%$, alternate with more gentle slope sectors of generally less than 1\% (Fig. 13C). We have labelled them as sectors I to IV in an upstream direction. Whichever valley is considered, the deepest nickpoints delimiting Sector I from Sector II are located at roughly similar depths, ranging from $1550 \mathrm{~m}$ (Rhône network) to $1850 \mathrm{~m}$ (Languedoc-Roussillon network, beneath the outer shelf). The longitudinal profiles of the Orb, Têt-Tech and Rhône courses extend far inland (Messinian canyons) and can be subdivided into four distinct sectors, whereas those of the Messinian Berre and proto-Aude valleys do not extend onshore and display only three distinct sectors (Fig. 13C). The identified fluvial sectors can be mapped along the Gulf of Lions margin and, when brought together, display four distinct geographic regions (Fig. 13D). 


\subsubsection{Borehole correlations}

The MES has been tied in to several boreholes. Figure 14 illustrates the stratigraphic correlation with the Cicindèle and Agde Maritime exploration wells and the presence of the Messinian discordance at the base of the Plio-Quaternary deposits. In the Cicindèle well, the correlation shows an unconformable contact between the Pliocene sediments and the Jurassic dolomites incised by the MES. In the Agde Maritime well, the contact is with Lower Langhian clays.

Stratigraphic descriptions from the drilling reports of these two wells do not give a biostratigraphic analysis of the post-erosional sequence deposited above the discordance. Nevertheless, Cravatte et al. (1974) carried out a detailed analyse of planktonic foraminifera on four other wells in the Gulf of Lions. These authors observed the presence of Early Pliocene fauna in the deposits just above the MES (e.g. Sphaeroidinellopsis subdehiscens and Globorotalia margaritae in the Tramontane well; see also Lofi et al., 2003a), thus demonstrating the Early Pliocene age of the post-erosional lower sequence. In the Gulf of Lions, as in the rest of the Mediterranean, the Miocene/Pliocene boundary corresponds to the re-establishment of open marine conditions in the Mediterranean after the MSC.

\subsubsection{Magnitude of erosion on the Languedoc-Roussillon shelf}

We have estimated the volume of sediments eroded from the Languedoc-Roussillon shelf during the MSC as $3000 \mathrm{~km}^{3}$ (Fig. 15), which is equivalent to a 500-m-thick column of uncompacted sediments over the study area. This estimate is in agreement with the work of Steckler and Watts (1980) who calculated a mean value of at least $550 \mathrm{~m}$ of Miocene deposits removed from the shelf at the Autan, Mistral and Tramontane wells. The erosion minima are observed beneath the inner shelf, on the Sétoise high separating the Rhone from the Languedoc-Roussillon network, and on the Mistral high (Fig. 15). Preferential erosion occurred in the Messinian valleys and at the top of some Miocene structures, and maximum erosion was $1500 \mathrm{~m}$ in the south-western extremity of the platform. This maximum value is related to a) the presence in this area of the large Rascasse Miocene rollover (Mauffret et al., 2001), and b) the method we used to approximate the eroded volume assuming that the Rascasse rollover was eroded exclusively during the Messinian event (see Section 3.3 and Fig. 3). The amount is thus probably over-estimated, as the Rascasse structure may have been partially eroded before the initiation of the MSC. Nevertheless, the large amount of Messinian detrital deposits recovered downslope, i.e. seaward of this structure (see Section 5.3), strongly suggests that the Rascasse topographic high was a site of severe erosion during the MSC and consequently that it was at least partially preserved until 5.6 Ma.

\subsection{Unit D}

\subsubsection{Seismic facies}

A chaotic seismic unit shown locally by the seismic records at the top of the Miocene sequence beneath the slope and the outer shelf has been termed "Unit D". This unit, nowhere visible beneath the present-day inner and middle shelf, has the following seismic characteristics:

- beneath the upper to middle slope, it is an acoustically incoherent unit below the base of the Plio-Quaternary sequence (Figs. 8 and 9) and is characterised by a chaotic seismic facies, containing discontinuous, high-amplitude internal reflections. The base of the unit 
correlates with the MES and its contact with the underlying deposits is either clear and erosive or indistinct (Figs. 8 and 9).

- it extends beneath the lower slope where the chaotic seismic facies is locally transparent or reflection-free. The unit is onlapped by the Salt and Upper Evaporite units (Fig. 16). A lateral transition to the Salt is not excluded, at least locally. Below the Salt, it is not clear whether the distal part of Unit D passes laterally above the Lower Evaporites or whether it partly correlates with them. The latter would suggest that Unit D may be diachronous in this sector and have been deposited during the deposition of both the Lower Evaporites and the Salt.

- landward, beneath the outer shelf, a seismic unit made up of a package of discontinuous high-amplitude reflectors is observed at the base of the Plio-Quaternary sequence. Its base coincides with the MES (Fig. 17). This unit was mapped using the LRM96 seismic profiles and is restricted to the axial part of the Languedoc-Roussillon Messinian thalweg, located beneath the present-day head of the Aude submarine canyon. Because of its spatial extent, the unit is interpreted as the landward continuation of Unit D (Fig. 18).

\subsubsection{Spatial extent}

Unit D is present at the base of the Plio-Quaternary sequence, and downslope beneath the deep Salt and Upper Evaporites. Based on its seismic facies, we have been able to map the extent of the unit within the study area (Fig. 1). Although the base of Unit D cannot be identified precisely on all the seismic lines, the dense grid of seismic profiles has enabled an isopach map to be compiled with a good approximation (Fig. 18).

Unit $\mathrm{D}$ beneath the upper and middle slope consists of two distinct systems that merge downslope and display an abrupt foot basinward. To the east, the distribution of Unit D is strongly linked to the Languedoc-Roussillon fluvial system, constrained within the axial part of the narrow (20 km wide) NW-SE-oriented Messinian valley (Figs. 9 and 18). The landward extremity of this unit is located beneath the present-day outer shelf (Fig. 17). To the west, beneath the upper to middle slope, Unit D is more widespread, and occurs in the Rascasse Messinian valley located seaward of the Rascasse Miocene rollover (Fig. 9).

An estimate made from the isopach map of the volume of sediments stored in Unit D ranges from 900 to $1400 \mathrm{~km}^{3}$. The main depocentre is not located at the mouth of the vast Languedoc-Roussillon paleo-network, but in the lower part of the Rascasse network where the maximum thickness is $800 \mathrm{~m}$.

\section{Discussion}

\subsection{Morphology of the margin at the beginning of the crisis}

Our knowledge of the evolution of the Gulf of Lions area during the Miocene is a key to understanding the impact of the MSC event on the evolution of the margin. The morphology, lithology and structure of this area during the Late Messinian played determinant roles in shaping the Messinian topography, controlling the location, nature and volume of sediment erosion, and determining the modality of the erosion and sediment transfer to the deep basin.

At the onset of the MSC, the shelf break was located about $30 \mathrm{~km}$ offshore from the present-day shelf break (Gorini, 1993) and the basin was more than $2000 \mathrm{~m}$ deep (Lofi, 2002; Steckler et al., 2003). Recent work has shown that a significant extensional event occurred in the Late Miocene in the south-western sector of the Gulf of Lions shelf (Mauffret et al., 2001; 
Gorini et al., in press). The event was characterised by a set of northeast-striking normal faults with a clear and abrupt offset of Miocene deposits (Fig. 2). Offset along the major faults can be as much as several hundred metres. It is not clear whether the relief variations due to tilting of the Miocene deposits were produced before the MSC, i.e. during the Tortonian-Messinian (Lofi, 2002), or during the MSC (Mauffret et al., 2001; Gorini et al., 2003; Gorini et al., in press). Nevertheless, as most of the faults affecting the Miocene series are sealed by the Messinian unconformity, this tectonic episode was at least completed before the end of the MSC (i.e. before $5.33 \mathrm{Ma}$ ).

A possible relationship between the MES and the extensional Late Miocene event over the shelf should not be ignored; the Messinian unconformity could be related to tectonic deformation of the margin. Nevertheless, this tectonic deformation is only observed in the western part of the Gulf of Lions shelf (Fig. 2), whereas the MES can be traced beneath the shelf and slope from Cap Creus to Cap Sicié (south-east of the Rhone area; Gennesseaux and Lefebvre, 1980; Guennoc et al., 2000; Lofi et al., 2003b). In addition, the occurrence of Early Pliocene deep-water deposits above the Messinian relief (Lofi et al., 2003a) and the lateral stratigraphic correlation of the MES with the deep evaporite sequence in the basin are convincing arguments supporting the correlation of our Messinian discordance with the MSC event. However, the influence of Late Miocene structures on the morphology of the MES in the western sector of the Gulf of Lions shelf is clear (see Gorini et al., in press, and Section 5.2.3). We can thus hypothesise that if the tilting of the Miocene deposits occurred before the onset of the MSC, then it is probable that the Messinian valleys would have followed the preexisting deformation structures. The Messinian valleys on the western shelf could thus constitute a kind of long-lived feature dating back to pre-Messinian times.

\subsection{Erosion of the margin during the formation of the MES}

\subsubsection{Evidence for subaerial erosion}

The MES in the Mediterranean is visible in seismic reflection profiles over many continental margins and is generally interpreted as the product of subaerial erosion, essentially by river action (Rizzini et al., 1978; Ryan and Cita, 1978; Barber, 1981; Stampfli and Höcker, 1989; Field and Gardner, 1991; Escutia and Maldonado, 1992). In the Gulf of Lions, fluvial action is indicated by the entire morphology of the MES with its many incisions forming an intricate fluvial drainage network (Figs. 11 and 12) that can be traced basinward beneath the slope. Beneath the shelf, few regions were spared from erosion and the MES portrays a badland morphology of gullies, spurs and mesas (Fig. 12). Spur crests and mesa tops are eroded and only some areas really close to the coast, and between the excavated canyons onshore, may have been preserved from erosion. Borehole analysis and seismic lines show that the MES locally incises consolidated sequences (e.g. Fig. 6A, shot points 2200 to 2500) such as the Jurassic dolomites intersected by the Cicindèle well (Fig. 14A). Because submarine slides or slumps cannot propagate through hard rock (and as far as $400 \mathrm{~km}$ on land in the case of the Rhone Messinian thalweg), we exclude a submarine origin in this sector of the margin.

Detailed observation of the MES beneath the shelf shows that a complex pattern of small tributaries developed on the flank of the main valleys. The origin of these incisions could be related to meteoric rain. Even though rainfall on the north-western Mediterranean coasts was not abundant at the end of the Miocene (Suc and Bessais, 1990), it can be surmised that atmospheric circulation may have been briefly, but significantly, perturbed during the MSC, as a result of the considerable evaporation over the basin. It has, for example, been demonstrated that the disappearance of an epicontinental sea can influence global atmospheric 
circulation (Fluteau et al., 1999). Consequently, short but intense rains may have affected the borders of the Mediterranean Basin during the evaporitic drawdown (Chamley and Robert, 1980) and contributed to the erosion of the margins.

The magnitude of the MSC sea-level drop in the Western Mediterranean Sea can be estimated from the depth of the Messinian Upper Evaporites in the deep basin, corrected for the effects of post-Messinian vertical movements and compaction (Lofi, 2002; Steckler et al., 2003). For example, the Upper Evaporites sampled south of the Balearic Islands contain stromatolites and anhydrite nodules characteristic of arid shallow-water depositional environments. According to these interpretations, the sea-level drop was at least as much as the depositional depth of the Upper Evaporites. This interpretation is reinforced by the existence of channels at the top of the evaporite sequence in the Valencia Trough (Escutia and Maldonado, 1992) and, in the Gulf of Lions, by the basinward extension of the MES beneath the Upper Evaporites down to depths exceeding 4 sec TWTT (Fig. 10).

Within the study area, the MES extends beneath the Salt unit and passes either along the top or along the base of the supposed Lower Evaporite unit (Fig. 10). The subaerial/subaqueous nature (and depth of extension) of the MES beneath the onlap of the Upper Evaporites is still matter of speculation. Here we lack crucial information concerning the nature of the Lower Evaporites and the thickness of the water column before, during and after Salt precipitation that would allow us to assess how far the MES extended basinward and how it formed in this area. A subaerial origin beneath the Salt onlap is not excluded, and would imply the formation of a subaerial erosion surface before the deposition of the Salt. In other words, the fall in sea level would have reached a maximum before Salt precipitation in the basin. Under this hypothesis, the flowing Salt layer and Upper Evaporites onlapping the MES (Fig. 10) would reflect a progressive filling of the Mediterranean Basin by these deposits. Extension of the MES beneath the Salt unit was also observed by Escutia and Maldonado (1992) in the Valencia Trough. These authors described multiple phases of Messinian erosion in this area, the most recent creating channels at the top of the evaporite sequence, and interpreted them as reflecting alternating episodes of the Atlantic advancing into and retreating from the Mediterranean. These multiple phases could nevertheless also reflect variations in the western Mediterranean base-level due to climatic changes, such as increased/decreased periods of runoff. The seismic records provide no evidence of such multiple erosion events within our study area. The fact that they are noted in the Valencia Trough could be because its very low basin-floor gradient favoured and enhanced the registration of even very slight variations during the drop in sea level.

\subsubsection{Subaqueous phenomena}

It appears evident that the Gulf of Lions margin was exposed during the "desiccation" phase, i.e. after 5.6 Ma, and that consequently the MES beneath the shelf and slope was shaped by subaerial processes. This does not, however, imply that all the erosion on the shelf and slope was due only to subaerial processes; other processes, including submarine slides, may have contributed to part to the margin erosion.

Before the beginning of the MSC, the Miocene shelf in the Languedoc-Roussillon area consisted of soft unlithified Late Miocene marls, muds and sands. Consequently, it is highly probable that the sea-level fall to below the Miocene shelf break after 5.6 Ma created instabilities, i.e. once the strata lost the buoyancy provided by their former submersion. The sediments may have dewatered through aquifers, with the sapping of the groundwater triggering avalanches and enhanced mass-wasting. The result would have been a massive transfer of Miocene sediments down to the lower slope and into the basin prior to any significant accumulation of the Salt and Upper Evaporites in the basin. A large part of the 
deposits eroded from the margin during the MSC may consequently be present as turbidites and debris flows on the deep basin floor below the Salt. If this should be the case, then we must question the nature of the so-called Lower Evaporites, which have never been sampled. The strong conformable reflectors of the Lower Evaporite seismic unit could well be caused by interbedded sands and muds, and their possible onlap geometry on the MES beneath the lower slope (Fig. 10). Such an interpretation reflects the diachronous and polygenic character of the MES which, with the increasing fall in sea level, would have evolved upslope to a subaerial surface whereas downslope it would have been rapidly buried by the Lower Evaporites, the Salt and the Upper Evaporites. Since fluvial erosion persisted throughout the MSC, the Salt and Upper Evaporites may also contain a large percentage of detrital sediments.

Gorini et al. (in press) suggest that the important sea-level fall during the MSC and the increase in seawater density in the deep basin may have caused an isostatic rebound sufficient to destabilise the entire margin during the crisis. Under this hypothesis, the catastrophic deformation of the Miocene cover should have favoured the creation of gigantic submarine landslides, particularly on the southern flank of high structures such as the Rascasse rollover (Fig. 2A).

\subsubsection{Control of the longitudinal profiles of the rivers}

Depth plots of the Messinian river-channel thalwegs in the Gulf of Lions against valley distance reveal both concave-up and concave-down sections in the current valley profiles (Fig. 13). In an attempt to understand the major driving forces that prevailed during their formation, two principal factors can be considered to account for these peculiar profiles: tectonism and/or eustasy.

Tectonic (structural) control: On the shelf, the structural axis of the Oligo-Aquitanian rifting and the superimposed Miocene structures would have strongly influenced the Messinian fluvial courses (Gorini et al., in press), with the rivers following the deformation structures of the Miocene sequence. Evidence in support of this, is that: 1) the drainage divide separating the Languedoc-Roussillon paleo-network from the Rhône paleo-network runs alongside a transfer zone, the Sétoise high, inherited from the rifting (Figs. 11, 12 and 15); 2) Gennesseaux and Lefebvre (1980) have shown the control of shallow structures on the Rhone's Messinian paleo-course in the eastern part of the margin; and 3) the deep structures of the rift in the western part of the margin are reflected by the NE-SW and the NW-SE orientations of the fluvial network (Lofi, 2002; Gorini et al., in press) with:

- the tributaries of the Languedoc-Roussillon system all converging above the central graben, which has been a zone of high subsidence and accommodation since its creation;

- the course of the Languedoc-Roussillon systems beneath outer shelf following a transfer zone separating the lateral horsts of Mistral (to the east) and Rascasse (to the west);

- the Messinian Rascasse fluvial system developing on the southern flank of the Rascasse Miocene anticlinal rollover, while the Têt-Tech network was constrained to bypass this structure to the west and to join the Languedoc-Roussillon system on the outer shelf (Fig. 11).

The influence of the rift and the Miocene structures on these Messinian fluvial courses is obvious, and it may well have been a structural control at the origin of the concave-up and concave-down longitudinal profiles of the Messinian valleys. The gentle slopes of sectors II (Fig. 13) roughly match with the north-western flank domain of the Rascasse rollover structure (Fig. 4, shot numbers 1000 to 2400), whereas sectors III may have been controlled by the south-eastern dipping strata of the Miocene sequence (Fig. 4, shot numbers 0 to 1000). 
Nevertheless, the Miocene deformation affects only the western part of the Gulf of Lions margin, whereas the longitudinal profiles of the rivers are similar from the Rhône area to the Tech Roussillon area, i.e. at the full scale of the margin. In addition, there is a strong lithological and structural contrast between the two extremities of the Gulf of Lions. In the eastern domain, the Messinian Rhone eroded the thin Miocene cover and incised a 600-mdeep canyon in the dolomitic Mesozoic substratum (Gennesseaux and Lefebvre, 1980). In the western domain, the Languedoc-Roussillon rivers eroded the thick faulted Miocene cover of relatively homogeneous soft material (silty marl or clay, as intersected by the Tramontane and Mistral wells). Consequently, the morphological similarity of the longitudinal Messinian river profiles may not be exclusively due to tectonism.

Eustatic control: As the overall morphology of the MES reflects a fluvial network, the shaping of the MES must to a great extent result from the action of the Messinian rivers cutting back into the shelf to adjust their base levels to the falling sea level. Consequently, another hypothesis is that changes in sea level during the "desiccation" phase (after 5.6 Ma) may have played a prevalent role in shaping the longitudinal profiles of the Messinian valleys.

The (flat-)steep-flat-steep profiles of the Messinian valleys can be accounted for by applying Schuum's (1977) concept of the dynamic metastable equilibrium of rivers. Here, the longitudinal profiles of the rivers could be interpreted as the result of two successive major sea-level falls in the western Mediterranean Basin during the Messinian "desiccation” phase (Fig. 19) with:

- $\quad$ sectors II and III resulting from the first phase of sea-level fall, after 5.6 Ma (Fig. 19B). A lowering of a few hundred metres would lead to a rapid seaward shift of the river mouths below the Miocene shelf-break and to their deep retrogressive downcutting across the shelf (Fig. 19C). As a result, Sector II along the Rhone extends far to the north (Fig. 13D) probably because of the large catchment area of this system. The break in gradient between sectors I and II could partly be a relic of the original Miocene shelf-break.

- Sector I being created during a second phase of sea-level lowering exposing the middle to lower parts of the continental slope (Fig. 19D). The high relief of the MES beneath the shelf would then result from prolonged exposure to subaerial erosion (compared to the slope domain that remained submerged during the first phase). Despite the greater amplitude of the second sea-level fall, we believe that the preservation of Sector II may due to its short duration.

- Sector IV resulting from vertical downcutting by the upstream parts of the rivers (Fig. 19, C to G). Despite the absence of an onshore Messinian canyon related to the Berre and Aude networks, the erosion observed offshore is significant (Fig. 13). Present-day evidence of karsts in their badlands (Peybèrnes and Combes, 1999) suggests that karstic resurgences may have been at the origin of the incisions noted beneath the shelf.

According to this eustatic hypothesis, the (flat-)steep-flat-steep profiles of the Messinian valleys would be the result of a temporary stillstand in the overall lowering of the base level (i.e. after $5.6 \mathrm{Ma}$ ). The initial fall could reflect the water body of the Western Mediterranean dropping to an intermediate sill, as it recorded only a modest rise in salinity due to the continued influx of Atlantic water (Blanc, 2000; Ryan and Pitman, 2000); a phenomenon suggested by Blanc (2000) who modelled the salt and water budget of the Mediterranean Sea during the MSC. The hypothesis of a two step sea-level fall would notably explain the large amount of Salt in the Western Mediterranean Basin while the marine water inflow was at the Atlantic straits.

There is strong evidence for a tectonic control on the river network pattern, and it is highly probable that the longitudinal profiles of the Messinian valleys were at least in part 
controlled by Miocene structures. Nevertheless, in view of the spectacular variations in sea level during the "desiccation" phase, eustasy may well have played the dominant role in shaping these profiles during the Messinian. If such is the case, then the MSC would provide one of the greatest illustrations of the famous cyclic concept of river life (Davis, 1899) and river equilibrium profile adjustment. Additional work on the Miocene sequence of the Gulf of Lions may help determine the relative eustatic and tectonic controls more clearly. In addition, the eustatic hypothesis should, if possible, be tested by tracing the longitudinal profiles of some Western Mediterranean Messinian rivers in a relatively stable tectonic context.

\subsection{Products of the margin erosion}

\subsubsection{Age and nature of Unit D}

In the absence of boreholes, the age and lithology of Unit D can only be derived indirectly from seismic stratigraphic analysis. Nevertheless, some observations and lines of reasoning can help narrow down the potential time window. Beneath the outer shelf to middle slope, Unit D lies above the MES and is directly overlain by the Early Pliocene prograding deposits; this suggests a pre-Early Pliocene age, but after the creation of the MES in this area (Figs. 8, 9 and 17). Unit D also extends downslope beneath the Upper Evaporites, the Salt and the top of the Lower Evaporites (or locally correlates laterally with these deposits; Fig. 16), which suggests an age older than or synchronous with the deposition of the evaporite sequences in the deep basin. These observations illustrate the complexity in attempting to precisely date Unit D and its internal diachroneity. They also suggest a strong relationship between this unit and the Messinian markers. We consequently propose a Messinian age for Unit D, although an earliest Pliocene age is not excluded locally, as will be discussed later. In addition, the chaotic seismic facies of this unit and its geographic extension (south of the Rascasse Miocene rollover and in the axis of the Messinian valleys; Figs. 8, 9 and 18) suggest a clastic origin. Unit D may therefore contain "Messinian detrital fan" type slope deposits that had been eroded from the margin during the MSC. Such sedimentary accumulations have already been described in the literature at the mouth of Messinian valleys elsewhere (Barber, 1981; Savoye and Piper, 1991; Sage et al., in press).

Fluvio-deltaic origin: The seismic facies of Unit D differ strongly from the overlying Early Pliocene deep-water deposits, which suggests a higher energy/shallower depositional environment and/or coarser or slumped deposits. Unit D may therefore be equivalent to the undated conglomerates sampled at the base of the Early Pliocene marls in some of the Gulf of Lions exploration wells (Mistral or GLP2). At Mistral, these conglomeratic deposits (sandy clay with abundant millimetre- to multicentimetre-size rock debris) contain benthic fauna characteristic of a littoral depositional environment (Cravatte et al., 1974; Lofi et al., 2003a). In the axial part of the Languedoc-Roussillon and Rascasse valleys, Unit D may also consist of shallow-water clastic sediments (fluvio-deltaic deposits?) accumulated during the MSC when the sea level was lower, and possibly also during the transgression at the end of this event (these deposits would then locally be of earliest Pliocene age).

We have also to take into account the hypothesis of slope-failure gravity deposits being at the origin of the chaotic facies of Unit $\mathrm{D}$, whereupon the erosive base of this unit could be interpreted as a rupture surface of a slumped system. However, the shallow-water fluvial interpretation is strongly supported by similar features described in the literature. In the Nile system, for example, a seismic chaotic unit is present in the axis of the Messinian paleo-Nile thalweg, lying above the MES that here truncates underlying Tortonian prodelta shales (Barber, 1981). Drilling of this chaotic unit has shown it to consist of fluvio-deltaic clastic 
deposits (sands, sandstones and conglomerates interbedded with clay layers) that have been termed the Qawasim Formation. Rizzini et al. (1978) initially interpreted this formation as being topped by the MES, but Barber (1981) noted the existence of a discordance both beneath and above this formation, and so dated the deposits as Messinian (syn-crisis) (see Fig. 2 of Barber, 1981). The Qawasim Formation is overlain either by Early Pliocene deepwater prodelta shales containing fauna of the Sphaeroidinellopsis $s p$. biozone, or by the Rosetta Formation (interbedded layers of clay and anhydrite) interpreted as the landward equivalent of the deep basin Upper Evaporites. It is worth noting the strong analogy with our Unit D, which is overlain either by the Early Pliocene prograding deposits beneath the outer shelf to middle slope (Figs. 8 and 17), or by the Upper Evaporites (and Salt) beneath the lower slope (Fig. 16).

Subaqueous mass gravity-flow deposits: The fact that Unit D locally extends under the Salt (Fig. 16) implies its deposition prior to the precipitation of Salt in the basin. Consequently, the distal (and older) part of the detrital unit may consist of resedimented detritus accumulated downslope in a subaqueous depositional environment, i.e. before significant "desiccation" was attained. This could result from a rapid and early loss of the Miocene outer-shelf deposits as soon as the sea level fall began, at about 5.6 Ma (Fig. 19A). This transfer may have been highly favoured by a short base-level stillstand during the overall "desiccation" phase (see Section 5.3.2 and Fig. 19B).

As illustrated by the isopach map of Unit D (Fig. 18), the main depocentre is observed in the western detrital fan system (Rascasse fan). We believe that the huge amount of detrital sediments in this area reflects the landward presence of the Rascasse rollover, which would have formed a topographic high during the MSC and supplied the material deposited in the detrital fan (Fig. 2A). The volume and distribution of the detrital downslope deposits would therefore appear to be linked directly both to the pre-existing Miocene relief on the margin and to the location of the Messinian rivers.

The Rascasse detrital fan was connected to a very small fluvial system compared to the Languedoc-Roussillon fan (Fig. 10) and linear erosion by the rivers would have deeply incised the flank of the Rascasse rollover rather than flatten it (Fig. 2A). The main erosion of the Rascasse high probably involved dominant mass-wasting or avalanche processes rather than fluvial processes. This supports the idea of massive sediment transfer to the basin under gravity flows during the MSC.

\subsubsection{Detrital fan growth}

Unit D is interpreted as a detrital fan deposited on the slope during the MSC. As indicated by the seismic profiles, this fan lies above the MES beneath the outer shelf to middle slope and extends downslope below the Salt and Upper Evaporites. Such a complex stratigraphic relationship with the Messinian markers suggests that 1) the deposition of the entire detrital fan was not a synchronous event, and that 2) the depositional environments (subaqueous/subaerial) may differ significantly within the sedimentary edifice. The observations that we have outlined here enable us to propose the following sketch for the growth of the Messinian detrital fans (Fig. 19):

- the presence of a large amount of detrital deposits below the Upper Evaporite and Salt units (Fig. 16) could have resulted from an "early" erosion of the margin, involving largescale submarine instabilities on the shelf break, upper slope and Rascasse rollover. This would have occurred before maximum lowering was reached (Fig 19B and C). Instability of the shales may have been increased by abnormal pressures following the rapid fall in sea level, triggering sliding and slumping phenomena. 
- the flowing Salt layer onlapping the MES and the distal part of Messinian detrital fans (Figs. 10 and 16) would then reflect a progressive filling of the basin by the thick evaporites, once the maximum "desiccation" phase had been attained (Fig 19D and E).

- the accumulation of detrital deposits in the excavated slopes of the Messinian valleys beneath the upper and middle slope (Figs. 8 and 9) suggests a fluvio-deltaic origin for these deposits. Their presence above the MES may reflect their retrogradation in the Messinian thalwegs accompanying the rise in base level as the Salt and Upper Evaporites thicken on the basin floor and the mean shoreline of the Salt basin shoals through aggradation (Fig 19E and F).

Where the Languedoc-Roussillon margin is concerned, the erosion and accumulation budgets do not balance. Calculated volumes suggest that the amount of sediment eroded from the margin during the MSC is at least 55 to $70 \%$ greater than the amount of sediment stored in the detrital fans beneath the slope. Although the exactitude of these volumes is limited by the assumptions made for the calculation, there is still an enormous excess which is likely to be found interbedded in the Salt and Upper Evaporites. A substantial part of sediments eroded from the outer shelf before Salt deposition may also be incorporated in turbidites and debris flows on the basin floor (possibly as part of the Lower Evaporites? - Fig. 19B). This interpretation is supported by the seismic data, which indicate that the detrital deposits pass laterally to the top of the Lower Evaporites (Fig. 16).

\subsection{End of the Messinian Salinity Crisis}

The MSC ended at 5.3 Ma with the return of open marine conditions allowing full circulation within the Mediterranean Sea. The sea-level rise following the "desiccation" has been traditionally envisaged as a rapid event involving a Pliocene inundation from the Atlantic (Hsü et al., 1973). Deep-sea marls overlying the Upper Evaporites in the western and eastern Mediterranean basins support this interpretation (Ryan et al., 1973; Pierre et al., 1998). Budget modelling and hydraulic calculations also suggest catastrophic refilling of the basin (Blanc, 2002). Nevertheless, studies of marginal Messinian deposits have led some authors to consider a less catastrophic Late Miocene transgression than previously envisaged (Krijgsman et al., 1999a).

In the Gulf of Lions, the concept of a rapid transgression is supported by seismic interpretation and borehole data. Strike profiles, at least over the modern inner-to-middle shelf and at the seismic resolution scale (30-50 m), show the absence of any transgressive system tracts above the MES (Fig. 6B). At the Agde Maritime well, seismic profiles and sedimentary analysis indicate a sharp contact between the Pliocene sediments and the Lower Langhian clays (Fig. 14). In addition, faunal analysis at the Tramontane well suggests middle-to-outer shelf depositional environments for the deposits just above the MES (Cravatte et al., 1974). The Tramontane well, however, was drilled on a Messinian topographic high and so transgressive sediments could have been deposited in the Messinian thalwegs as the river mouths retreated on the shelf. Nevertheless, except possibly beneath the outer-shelf and slope (Figs. 9, 17 and 19G), there are no seismic indications for transgressive deposits accumulated in the valley axes. At the Cicindèle well, a 15-m-thick sandstone unit overlain by Early Pliocene deep-water marls was sampled at the depth of the MES (Cravatte et al., 1974; Lofi et al., 2003a). The sandstones could be considered as a transgressive interval, but in view of the coarse lithology of the deposits, they could also correspond to Messinian detrital deposits eroded during the lowstand and subsequently abandoned when the sea level rose.

On the Nice margin, Savoye and Piper (1991) observed the downslope accumulation of $100 \mathrm{~m}$ of prodeltaic conglomerates and marls that they interpret as deposited at the beginning of the base-level rise corresponding to the end of the MSC. Such deposits are nowhere visible 
in present-day water depths of less than $1000 \mathrm{~m}$, which led the authors to suggest that the final stage of the transgression could have been extremely rapid. Within the study area, the apex of the Languedoc-Roussillon detrital fan is located beneath the outer shelf (Figs. 17 and 19G) and does not extend landward beneath the shelf (Fig. 18). We consequently join with Savoye and Piper (1991) in concluding that there was an accelerated transgression during the sealevel rise. The present-day depth of the Languedoc-Roussillon detrital fan apex is 1700$1800 \mathrm{~m}$, which ties in with the downstream nickpoint separating sectors I and II on the longitudinal profile of the Messinian rivers (Fig. 13 A and B). As this nickpoint may correlate with a temporary base-level stillstand during the overall base-level fall (Fig. 19B and C), corresponding to an intermediate sill between western and eastern Mediterranean, the acceleration of the transgression at the end of the crisis may also have been controlled by the presence of this sill.

\section{Conclusion}

The detailed registration of the history of the MSC in the Gulf of Lions resulted from two main factors. The first was an overall high subsidence and sedimentation rate during the Miocene that led to the construction of a thick wide continental shelf (Gorini, 1993); such a large shelf was easily shaped during the crisis and furnished a considerable amount of sediment to the basin. The second factor is the relative tectonic stability of the LanguedocRoussillon margin since the end of the crisis, as indicated by the unfaulted gently prograding Plio-Quaternary sequence (Lofi et al., 2003a), which enabled the Messinian markers to be preserved in a configuration close to their initial morphology.

The overall morphology and seismic characteristics revealed by the seismic reflection profiles for the MES, the detrital deposits and the evaporite sequences, provide more detailed information concerning the direct paleo-environmental evolution of the Gulf of Lions margin during the MSC. The most important observations are as follows:

1. The Late Miocene tectonic phase that affected the western shelf played an important role concerning the Messinian river patterns, the location of the maximum erosion on the shelf, and the location of the detrital depocentre downslope.

2. The emergence of the Miocene shelf was extensive during the MSC and a mature badland surface evolved in less than 300,000 years. Erosion was from mass wasting of unbuttressed water-bearing sediments, from river incision, and from stream cutting from karst springs.

3. Erosion prior to the significant accumulation of the Salt and Upper Evaporites was severe. Consequently, the detrital clastics deposited under the Salt could potentially form salt-sealed reservoirs for hydrocarbons, possibly making the basin floor a better prospective target than the margins themselves.

4. Erosion started as a retrogressive cutting of gullies, mass wasting and avalanches, and was augmented by rivers downcutting to adjust to their new base level. We have found evidence of particular longitudinal river profile morphologies that, with some caution, could be interpreted as resulting from a temporary base-level stillstand during the overall base-level fall. This first-phase sea-level fall could reflect an intermediate sill between the western and eastern Mediterranean basins.

5. Shoaling of the basin floor during the accumulation of the Salt and Upper Evaporites progressively reduced the river gradients and led to a filling of the lower valleys with clastic deposits. At the same time, the area of the basin floor expanded and its shoreline transgressed landward. 
The effect of the MSC persisted after its end. The Gulf of Lions margin had been flattened during the "desiccation", giving it a mean gradient of $1.5^{\circ}$, which is less than the normal stable slopes of passive margins (about $3^{\circ}$ ). This created a large space for accommodating post-Messinian sedimentation (strongly controlled by the morphology of the MES) in the onshore canyons, and beneath the shelf. To advance our understanding of the Messinian event and its long-term consequences on margin sedimentation, the evolution of the Gulf of Lions margin should be compared with that of margins presenting more contrasted tectonic, morphologic and geologic settings.

\section{Acknowledgements}

This work was undertaken as part of the ECLIPSE and GDR "Marges" (contribution no. 2044) research programmes. The authors wish to thank ELF EP for giving us access to the seismic data used in this study and for allowing their publication. The crews and technical staffs of L'Atalante and Le Suroit are thanked for their assistance during the "Calmar" and "Marion" cruises. We acknowledge journal reviewer J.C. Faugères and the editor-in-chief, D.J.W. Piper, for their advice and improvements to the manuscript. A special thanks to M. Roveri for our discussions and for his extremely constructive comments on reviewing the manuscript . 


\section{References}

Ambert, P., Aguilar, J.P., Michaux, J., 1998. Evolution géodynamique messino-pliocène en Languedoc central : le paléo-réseau hydrographique de l'Orb et de l'Hérault (Sud de la France). Geodinamica Acta, 11(2-3): 139-146.

Barber, P.M., 1981. Messinian subaerial erosion of the Proto-Nile delta. Marine Geology, 44(3-4): 253-272.

Benson, R.H., Rakic-El Bied, K., Bonaduce, G., 1991. An important current reversal (influx) in the Rifian Corridor (Morocco) at the Tortonian-Messinian boundary: the end of the Tethys Ocean. Paleoceanography, 6(1): 164-192.

Berné, S., Loubrieu, B., l'équipe embarquée, 1999. Canyons et processus sédimentaires récents sur la marge occidentale du Golfe du Lion. Premiers résultats de la campagne Calmar. Comptes Rendus de l'Académie de Sciences, 328: 471-477.

Biju-Duval, B., Letouzey, J., Montadert, L., 1978. Structure and evolution of the Mediterranean Basins. In: K. Hsü et al. (Editors), Initial Reports of the Deep Sea Drilling Project, Leg 42. U.S. Government Printing Office, Washington, pp. 951-984.

Blanc, P.L., 2000. Of sills and straits: a quantitative assessment of the Messinian Salinity Crisis. Deep-Sea Research, I(47): 1429-1460.

Blanc, P.L., 2002. The opening of the Plio-Quaternary Gibraltar Strait: assessing the size of a cataclysm. Geodinamica Acta, 15: 303-317.

Chamley, H., Robert, C., 1980. Sédimentation argileuse au Tertiaire supérieur dans le domaine méditerranéen. Géologie Méditerranéenne, 7(1): 25-34.

Chumakov, I.S., 1973. Pliocene and Pleistocene deposits of the Nile Valley in Nubia and Upper Egypt. In: W.B.F. Ryan, K.J. Hsü, M.B. Cita and e. al. (Editors), Initial Reports of the Deep Sea Drilling Project., pp. 1242-1243.

Clauzon, G., 1973. The eustatic hypothesis and the pre-Pliocene cutting of the Rhône valley. In: W.B.F. Ryan and K.J. Hsü (Editors), Initial Report of the Deep Sea Drilling Project, pp. 1251-1256.

Clauzon, G., 1978. The Messinian Var canyon (Provence, Southern France) - paleogeographic implications. Marine Geology, 27: 231-246.

Clauzon, G., 1982. Le canyon messinien du Rhône : une preuve décisive du "desiccated deepbasin model" [Hsü, Cita et Ryan, 1973]. Bulletin de la Société Géologique de France, 24(3): 597-610.

Clauzon, G., Suc, J.P., 2002. Did high sea-level exchanges occured between the mediterranean and the central Paratethys in the Late Miocene and the Earliest Pliocene? A new idea of the Lago Mare event(s). La crise de salinité messinienne : modalités, consequences régionales et globales, quantification. Réunion de fin de première année du programme ECLIPSE., Paris, pp. 7-8.

Clauzon, G., Suc, J.P., Gautier, F., Berger, A., Loutre, M.F., 1996. Alternate interpretation of the Messinian salinity crisis: controversy resolved? Geology, 24(4): 363-366.

Cravatte, J., Dufaure, P., Prim, M., Rouaix, S., 1974. Les sondages du Golfe du Lion : stratigraphie, sédimentologie, Notes \& Mémoires. Compagnies Françaises des Pétroles, pp. 209-274.

Davis, W.M., 1899. The geographical cycle. Geographical Journal., 14: 481-504.

Dos Reis, A.T., 2001. La Tectonique Salifère et son Influence sur l'Architecture Sédimentaire Quaternaire de la Marge du Golfe du Lion - Méditerranée Occidentale. Thèse de Troisième cycle Thesis, Université Pierre et Marie Curie - Paris VI, 373 pp.

Dos Reis, A.T., Gorini, C, Mauffret, A. Implications of salt-sediment interactions for the architecture of the Gulf of Lions deep-water sedimentary systems - Western Mediterranean Sea. Marine and Petroleum Geology, in press. 
Duggen, S., Hoernla, K., Van den Bogaard, P., Rupke, L., Morgan, J.P., 2003. Deep roots of the Messinian salinity crisis. Nature, 422: 602 - 606.

Duvail, C., Gorini, C., Lofi J., Le Strat P., Clauzon G. and Dos Reis A.T., in press. Correlation between onshore and offshore Pliocene-Quaternary systems tracts below the Roussillon Basin (eastern Pyrenees, France). Marine and Petroleum Geology.

Escutia, C., Maldonado, A., 1992. Palaeogeographic implications of the Messinian surface in the Valencia trough, north-western Mediterranean Sea. Tectonophysics, 203: 263-284.

Estocade, G., 1978. Messinian subaerial erosion of the Stoechades and Saint Tropez canyons a submersible study. Marine Geology, 27: 247-269.

Fauquette, S., Suc, J.P., Guiot, J., Diniz, F., Feddi, N., Zheng, Z., Bessais, E., Drivaliari, A., 1999. Climate and biomes in the West Mediterranean area during Pliocene. Palaeogeography, Palaeoclimatology, Palaeoecology, 152: 15-36.

Field, M.E., Gardner, J.V., 1991. Valencia gorge: possible Messinian refill channel for the western Mediterranean Sea. Geology, 19: 1129-1132.

Fluteau, F., Ramstein, G., Besse, J., 1999. Simulating the evolution of the Asian and African Monsoons during the past $30 \mathrm{Myr}$ using an atmospheric general circulation model. Journal of Geophysical Research, 104(D 10): 11,995 - 12,018.

Fortuin, A.R., Krijgsman, W., Hilgen, F.J., Sierro, F.J., 2000. Late Miocene Mediterranean desiccation; topography and significance of the "salinity crisis" erosion surface on-land in Southeast Spain; discussion and reply. Sedimentary Geology., 133(3-4): 167-184.

Gautier, F., Clauzon, G., Suc, J.P., Cravatte, J., Violanti, D., 1994. Age et durée de la crise de salinité messinienne. Compte Rendu de l'Académie des Sciences de Paris, 318(2): 11031109.

Gennesseaux, M., Lefebvre, D., 1980. Le Golfe du Lion et le Paléo-Rhône messinien. Géologie Méditerranéenne, 7(1): 71-80.

Gorini, C., 1993. Géodynamique d'une marge passive : le Golfe du Lion (Mediterranée occidentale). Thèse de Troisième cycle Thesis, Paul-Sabatier, Toulouse III, Toulouse, 256 pp.

Gorini, C., Le Marrec, A., Mauffret, A., 1993. Contribution to the structural and sedimentary history of the Gulf of Lions (Western Mediterranean), from the ECORS profiles, industrial seismic profiles and well data. Bulletin de la Société Géologique de France, 164(3): 353363.

Gorini, C. Bache, F., Duvail, C., Dos Reis, A.T., Olivet, J.L., Rabineau, M., Lestrat, P., Lofi, J., Mauffret, A.,, Berné, S., 2003. Genetic model of deposition for the Miocene of the Gulf of Lions (western Mediterranean) from seismic stratigraphy and well log correlation., $8^{\text {th }}$ International Congress of The Brazilian Geophysical Society , Rio de Janeiro, Brazil.

Gorini, C., Lofi, J., Duvail, C., Dos Reis, T., Guennoc , P., Berné, S., Le Strat , P., Mauffret, A., in press. The Late Messinian (5.6- 5.32 Ma) salinity crisis and Late Miocene tectonism : interaction and consequences on the physiography and post-rift evolution of the Gulf of Lions margin. Marine and Petroleum Geology.

Guennoc, P., Gorini, C., Mauffret, A., 2000. Histoire géologique du Golfe du Lion et cartographie du rift oligo-aquitanien et de la surface messinienne. Géologie de la France, 3: 67-97.

Hsü, K.J., Cita, M.B., Ryan, W.B.F., 1973. The origin of the Mediterranean evaporites. Initial reports of the deep sea drilling project. D.C., U.S. Government Printing Office, Washington, pp. 1203-1231.

Kastens, K.A., 1992. Did glacio-eustatic sea level drop trigger the Messinian Salinity Crisis? New evidence from ocean drilling program site 654 in the Tyrrhenian Sea. Paleoceanography, 7(3): 333-356. 
Krijgsman, W., Hilgen, F.J., Raffi, I., Sierro, F.J., Wilson, D.S., 1999a. Chronology, causes and progression of the Messinian salinity crisis. Nature, 400: 652-655.

Krijgsman, W. Langereis, C.G., Zachariasse, W.J., Boccaletti, M., Moratti, G., Gelati, R., Iaccarino, S., Papani, G., Villa, G., 1999b. Late Neogene evolution of the Taza-Guercif Basin (Riftian Corridor, Morocco) and implications for the Messinian salinity crisis. Marine Geology, 153: 147-160.

Le Pichon, X., Pautot, G., Auzende, J.M., Olivet, J.L., 1971. La Méditerranée occidentale depuis l'Oligocène. Schéma d'évolution. Earth Planetary Science Letters, 13: 145-152.

Lofi, J., 2002. La Crise de Salinité Messinienne : Incidences directes et différées sur l'évolution sédimentaire de la marge du Golfe du Lion. PhD thesis, Lille I, 285 pp.

Lofi, J., Rabineau, M., Gorini, C., Berné, S., Clauzon, G., De Clarens, P., Moutain, G.S., Ryan, W.B.F.,; Steckler, M.S., Fouchet, C., 2003a. Plio-Quaternary prograding clinoform wedges of the Western Gulf of Lion continental margin (NW Mediterranean) after the Messinian Salinity Crisis. Marine Geology, 198(3-4): 289-317.

Lofi, J., Gorini, C., Dos Reis, A.T., Berne, S., Mauffret, A., 2003b. La marge du Golfe du Lion et la Crise de Salinite Messinienne: devenir des produits de l'érosion? 9th congres de l'Association Française des Sédimentologues, Bordeaux.

Mauffret, A., Durand de Groussouvre, B., Dos Reis, A.T., Gorini, C., Nercessian, A., 2001. Structural geometry in the eastern Pyrenees and Western Gulf of Lion (Western Mediterranean). Journal of Structural Geology, 23: 1701-1726.

Montadert, L., Sancho, J., Fail, J.P., Debyser, J., Winnock, E., 1970. De l'âge tertiaire de la série salifère responsable des structures diapiriques en Méditerranée Occidentale (Nord-Est des Baléares). Compte Rendu de l'Académie des Sciences, Série D, 271: 812-815.

Orszag-Sperber, F., Rouchy, J.M., Blanc-Valleron, M.M., 2000. La transition MessinienPliocène en Méditerranée orientale (Chypre) : la période du Lago-Mare et sa signification. Comptes Rendus de l'Académie des sciences, 331: 483-490.

Peybèrnes, B., Combes, J.P., 1999. Paléosurfaces d'érosion et paléokarsts dans la série de passage Crétacé/Tertiaire des Corbières occidentales (Aude, France). Comptes Rendus de l'Académie des Sciences, 329: 815-822.

Pierre, C., Rouchy, J.M., Blanc-Valleyron, M.M., 1998. Sedimentological and stable isotope changes at the Messinian/Pliocene boundary in the eastern Mediterranean (holes 968A, 969A, and 969B). In: A.H.F. Robertson, K.C. Emeis, C. Ritcher and A. Camerlenghi (Editors), Proceedings of the Ocean Drilling Program, Scientific Results.

Réhault, J.P., Boillot, G., Mauffret, A., 1984. The Western Mediterranean Basin geological evolution. Marine Geology, 55(3-4): 445-475.

Riding, R., Braga J.C., Martin Jose, M., Sanchez Almazo Isabel, M., 1998. Mediterranean Messinian salinity crisis: constraints from a coeval marginal basin, Sorbas, southeastern Spain. Marine Geology, 146: 1-20.

Riding, R., Braga, J.C., Martin, J.M., 2000. Late Miocene Mediterranean desiccation: topography and significance of the 'Salinity Crisis' erosion surface on-land in the southeast Spain: Reply. Sedimentology Geology, 133: 175-184.

Rizzini, A., Vezzani, F., Cococcetta, V., Milad, G., 1978. Stratigraphy and sedimentation of a Neogene-Quaternary section in the Nile delta area (A.R.E.). Marine Geology, 27: 327-348.

Rouchy, J.M., Saint Marin, J.P., 1992. Late Miocene events in the Mediterranean as recorded carbonate-evaporite relations. Geology, 20: 629-632.

Roveri, M., Bassetti, M.A., Ricci Lucchi, F., 2001. The Mediterranean Messinian salinity crisis: an Apennine foredeep perspective. Sedimentary Geology, 140(3-4): 201-214.

Ryan, W.F., Hsü, K.J. et al., 1973. Initial Reports of the Deep Sea Drilling Project, 13, 1447 pp. 
Ryan, W.B.F., 1976. Quantitative evaluation of the depth of the western Mediterranean before, during and after the late Miocene salinity crisis. Sedimentology, 23(6): 791-813.

Ryan, W.B.F., Cita, M.B., 1978. The nature and distribution of Messinian erosional surfaces; indicators of a several-kilometer-deep Mediterranean in the Miocene. Marine Geology, 27(3-4): 193-230.

Ryan, W.B.F., Pitman, W.C., 2000. Modelling the Mediterranean's Messinian Salinity Crisis: chronology, sedimentary cycles, erosion surfaces and the role of sills, Atelier "Golfe du Lion", GDR "Marges", Paris, pp. 32.

Sage, F., Von Gronefeld, G., Deverchère, J., Gaullier, V.; Maillard, A., Gorini, C., in press. A record of the Messinian Salinity Crisis on the western Sardinia margin, Northwestern Mediterranean. Marine and Petroleum Geology.

Savoye, B., Piper, D.J.W., 1991. The Messinian event on the margin of the Mediterranean Sea in the Nice area, southern France. Marine Geology, 97: 279-304.

Schuum, S.A., 1977. The Fluvial System. John Wiley and Sons, New York, 338 pp.

Seidenkrantz, M.S., Kouwenhoven, T.J., Jorissen, F.J., Shackleton, N.J., Van der Zwaan, G.J., 2000. Benthic foraminifera as indicators of changing Mediterranean-Atlantic water exchange in the late Miocene. Marine geology, 163: 387-407.

Stampfli, G.M., Höcker, C.F.W., 1989. Messinian palaeorelief from 3-D seismic survey in the Tarraco concession area (Spanish Mediterranean Sea). Geologie en Mijnbouw, 68(2): 201210.

Steckler, M.S., Watts, A.B., 1980. The Gulf of Lion: subsidence of a young continental margin. Nature, 287: 425-429.

Steckler, M.S., Lofi, J., Mountain, G.S., Ryan, W.B.F., Berné, S., Gorini, C., 2003. Reconstruction of the Gulf of Lion margin during the Messinian Salinity Crisis., AGU, Nice (France).

Suc, J.P., Bessais, E., 1990. Pérennité d'un climat thermo-xérique en Sicile avant, pendant, après la crise de salinité messinienne. Compte Rendu de l'Académie des Sciences, 310(2): 1701-1707.

Suc, J.P., Drivaliari, A., 1991. Transport of bisaccate coniferous fossil pollen grains to coastal sediments: an example from the earliest Pliocene Orb ria (Languedoc, southern France). Review of Palaeobotany and Palynology, 70: 247-253. 


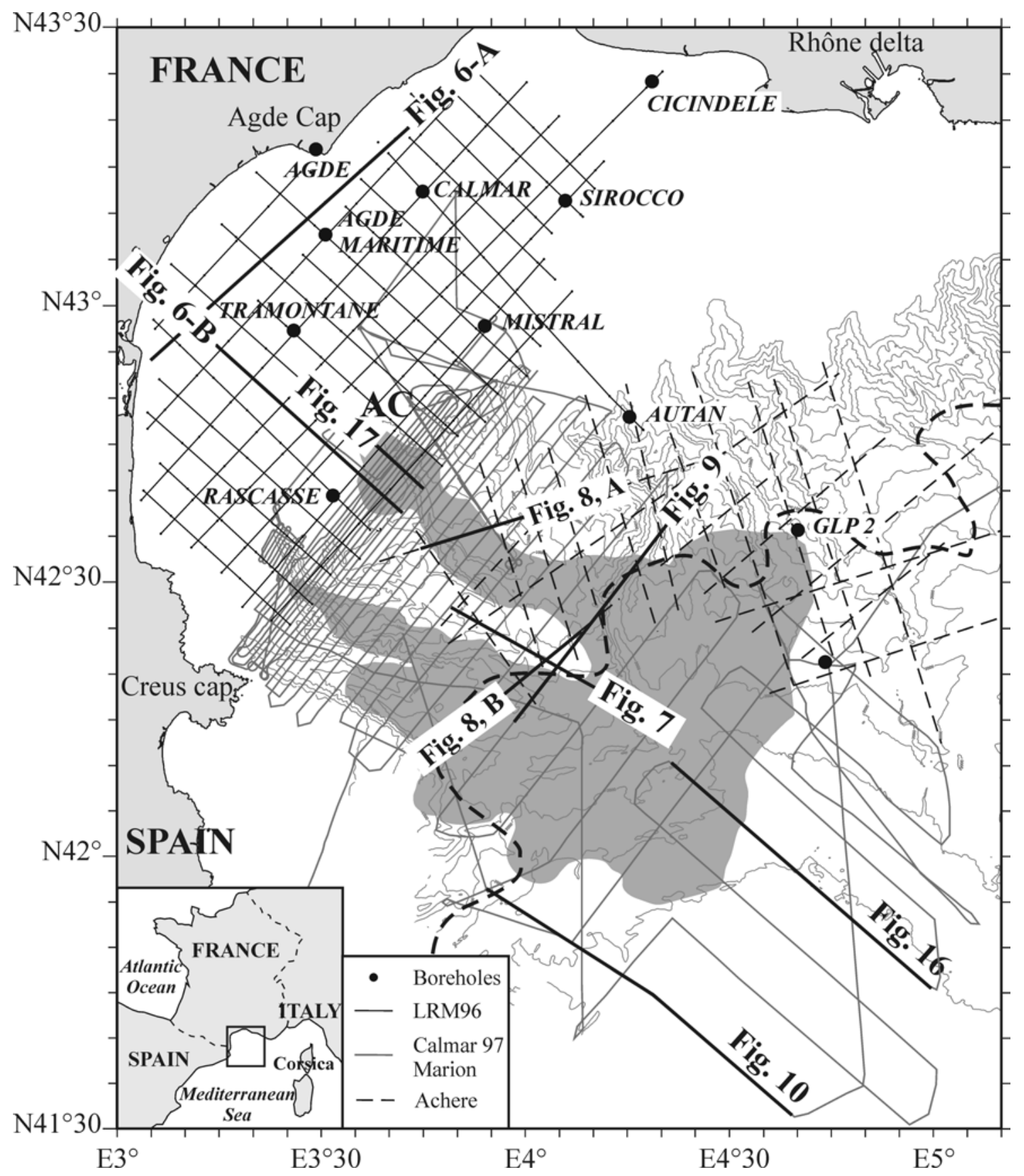

Fig. 1 - Simplified bathymetric map of the Gulf of Lions shelf showing the location of the study area, the seismic line grid and the exploratory wells. Dashed bold line: onlap of the Messinian Salt in the basin (after Dos Reis, 2001). AC: Aude (or Bourcart) present-day submarine canyon; Bold numbered sections: locations of the profiles in Figs. 6, 7, 8, 9, 10, 16 and 17; Dark grey: extension of a chaotic seismic unit (Unit D) shown on the seismic lines at the base of the Plio-Quaternary sequence, or beneath the Messinian Salt and Upper Evaporites, and interpreted as a Messinian clastic unit. 

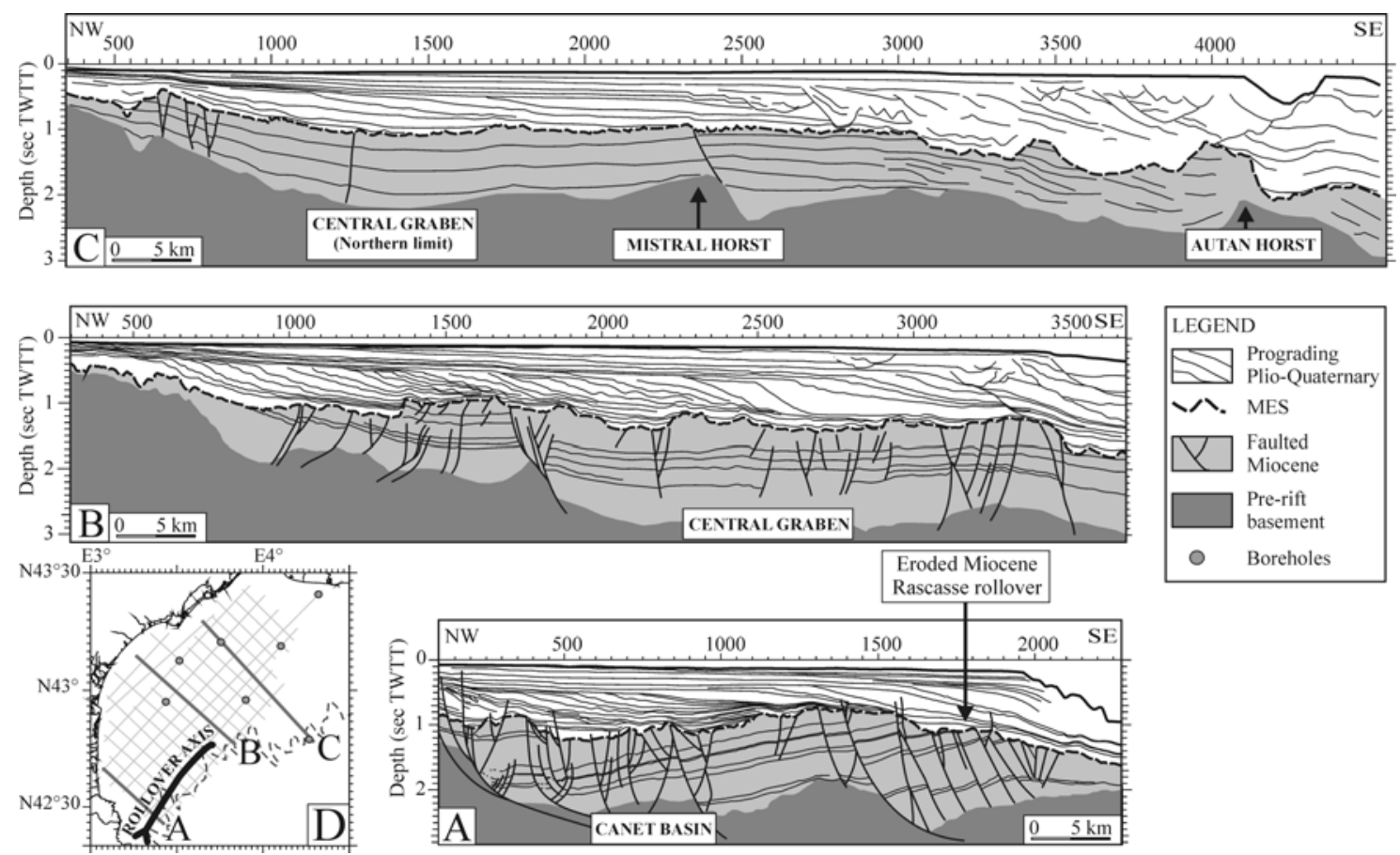

Fig. 2. Line drawings of the dip seismic profiles LRM04 (A) and LRM18 (B), modified from Duvail et al. (in press), and LRM28 (C) on the Gulf of Lions shelf illustrating the offset of the Miocene sequence by a number of normal late Miocene faults sealed by the Messinian Erosional Surface (MES). Note that the variations in relief due to tilting of the Miocene series decrease rapidly northeastward. The tilted Miocene series formed the Rascasse rollover structure that has been eroded. (D) Location of the Rascasse rollover axis (modified from Lofi, 2002); grey dashed line-present-day shelf break.

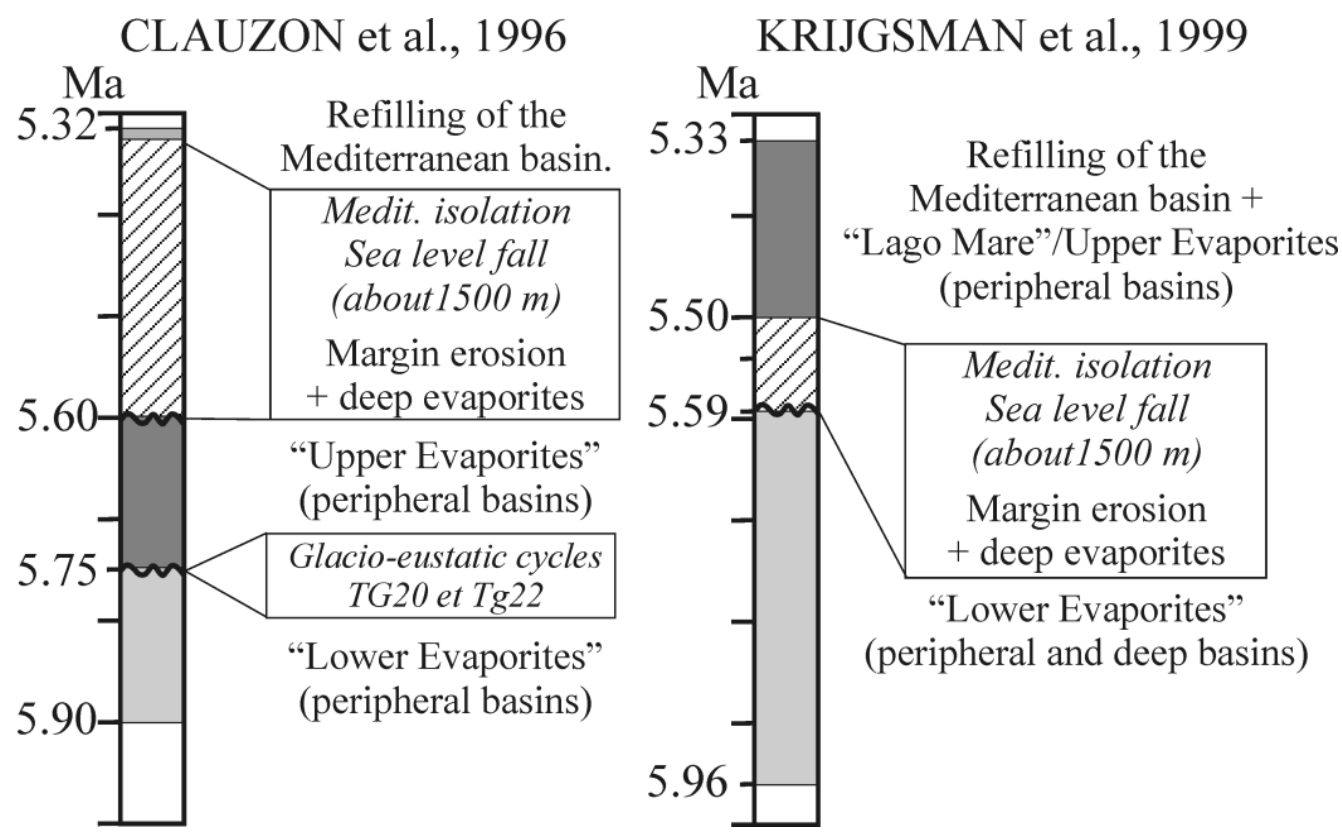

Fig. 3 - Comparison between the chronostratigraphic models proposed by Clauzon et al. (1996) and Krijgsman et al. (1999a) for the Messinian Salinity Crisis. Based on these models, we consider that the sea-level drop began at about 5.6 Ma. 


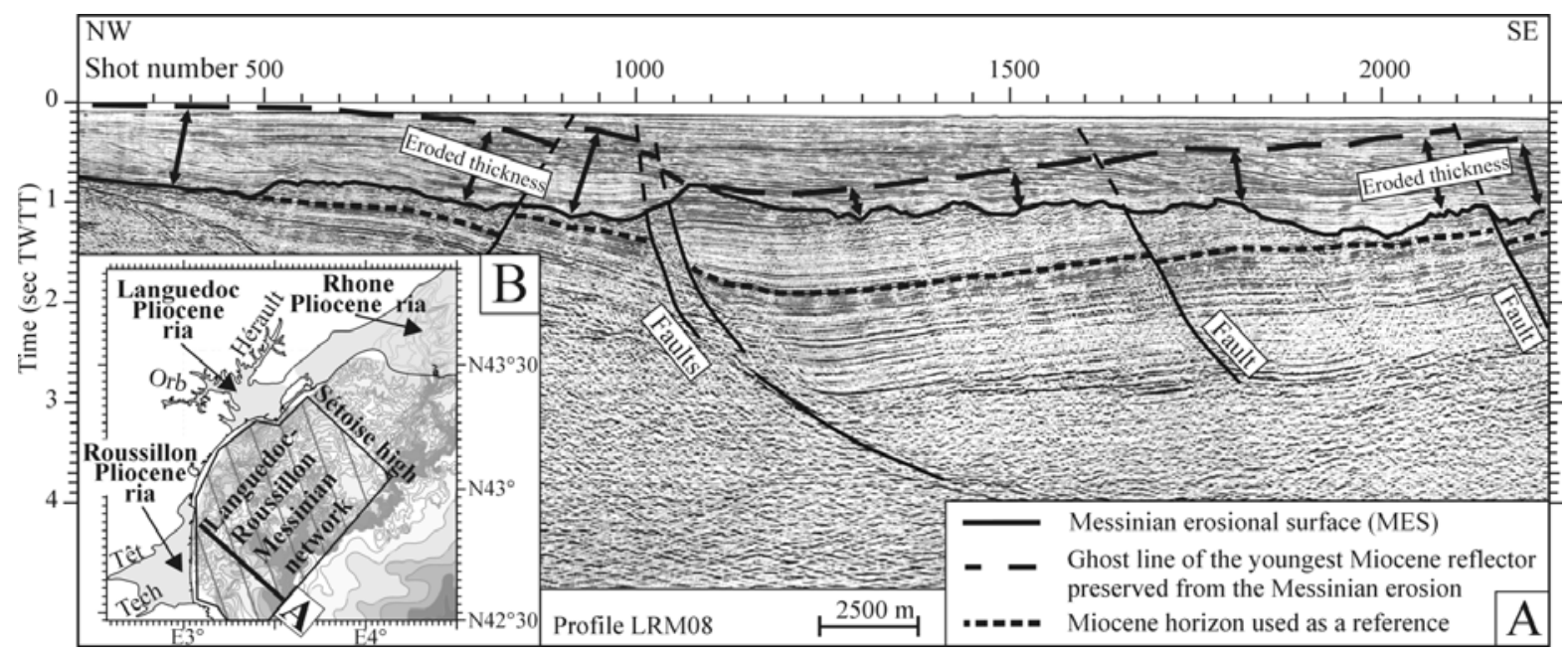

Fig. 4 - A: Seismic line illustrating the method (Mauffret et al., 2001) used to calculate the volume of sediments eroded from the shelf during the Messinian Salinity Crisis.

Black bold line: the Messinian Erosional Surface (MES); Black short dotted line: a Miocene horizon used as a reference to draw the "ghost" of the youngest Miocene reflector preserved from erosion (black large dotted line). The eroded volume is estimated between the ghost horizon and the MES using a constant velocity of $2000 \mathrm{~m} / \mathrm{sec}$. B: Study area. The volume eroded has been estimated beneath the present-day platform.

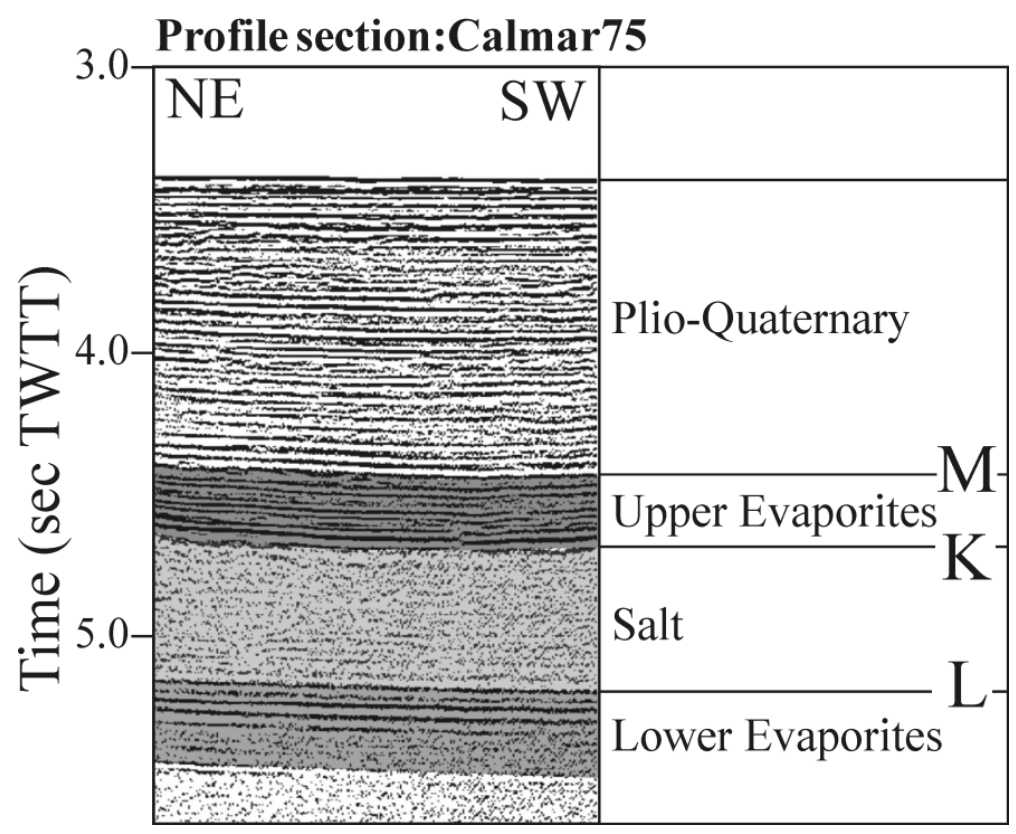

Fig. 5 - Portion of the Calmar75 seismic line illustrating the classical seismic facies of the Messinian deep-basin evaporite succession composed of the Lower Evaporites at the bottom, the Salt, and the Upper Evaporites at the top. Reflector references L, K and M, are respectively after Biju-Duval et al. (1978), Montadert et al. (1970) and Ryan et al. (1973). 

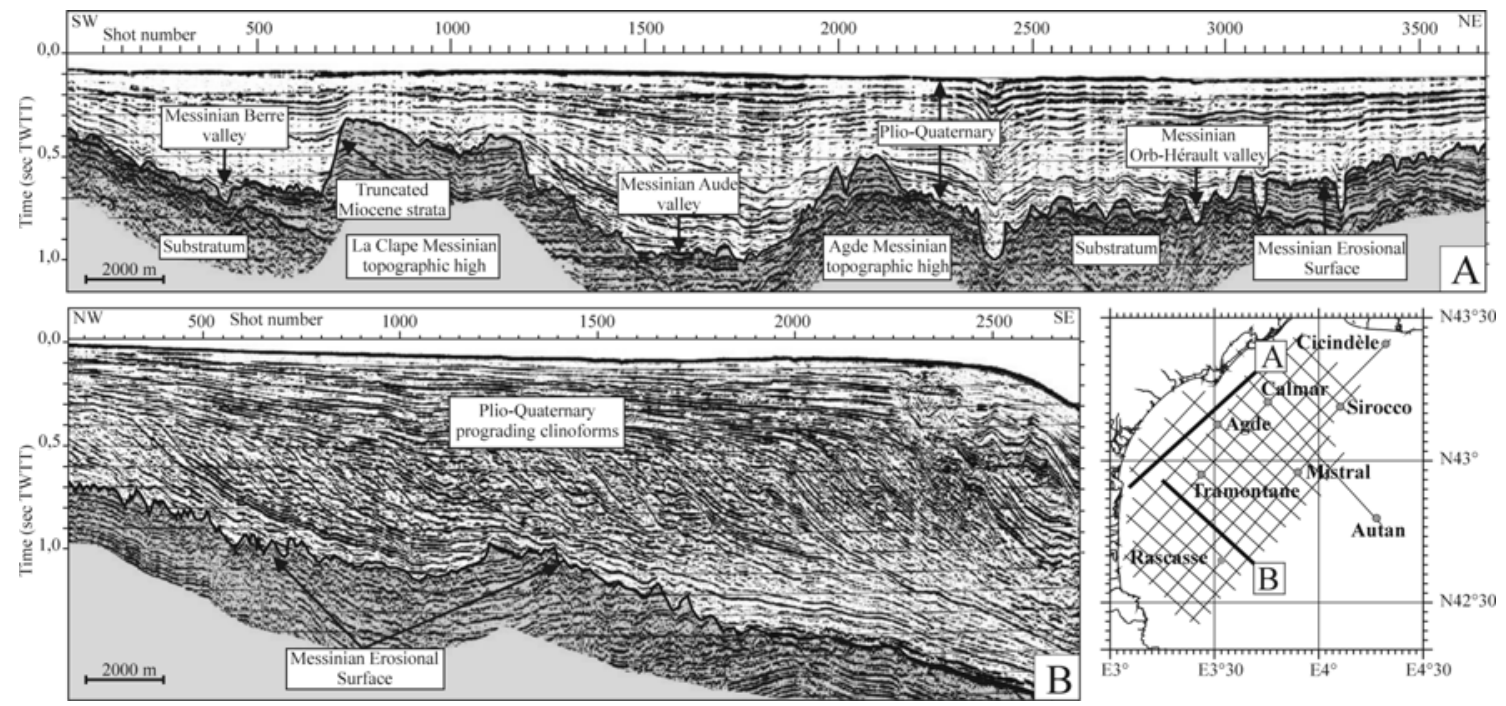

Fig. 6 - Strike seismic profile LRM15 (A) and dip seismic profile LRM12 (B) across the Gulf of Lions continental shelf, illustrating the erosional character of the Messinian Erosional Surface (MES) at the base of the Plio-Quaternary prograding sequence.

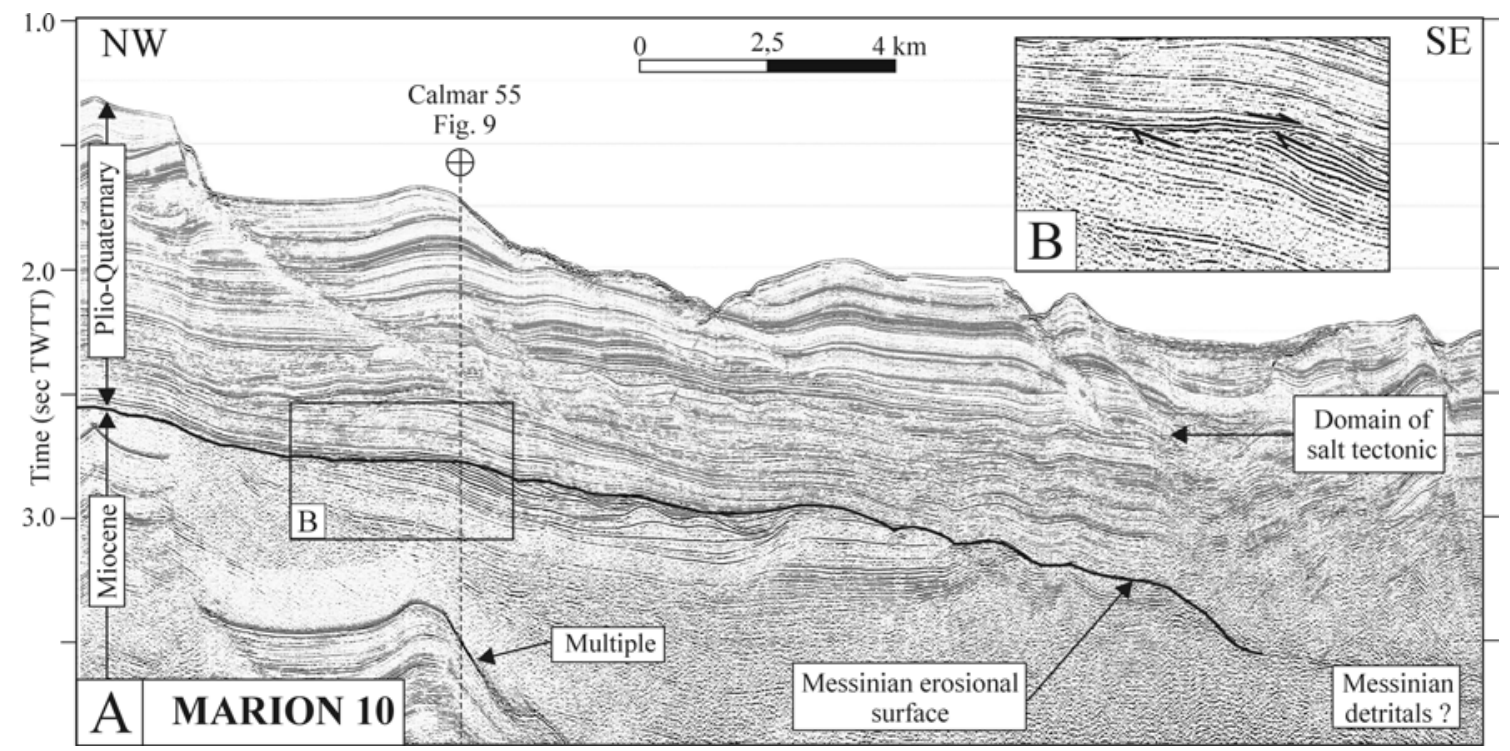

Fig. 7 - A: Dip seismic profile (Marion10, Ifremer) across the present-day slope (see position in Fig. 1). The Messinian Erosional Surface (MES) at the base of the prograding Plio-Quaternary sequence has a sharp erosional character. Downslope, the Plio-Quaternary deposits are faulted by salt tectonism.

B: Zoom on the MES illustrating the angular discordance between the toplaps of the eroded Miocene reflectors and the downlaps of the prograding Lower Pliocene reflectors. 

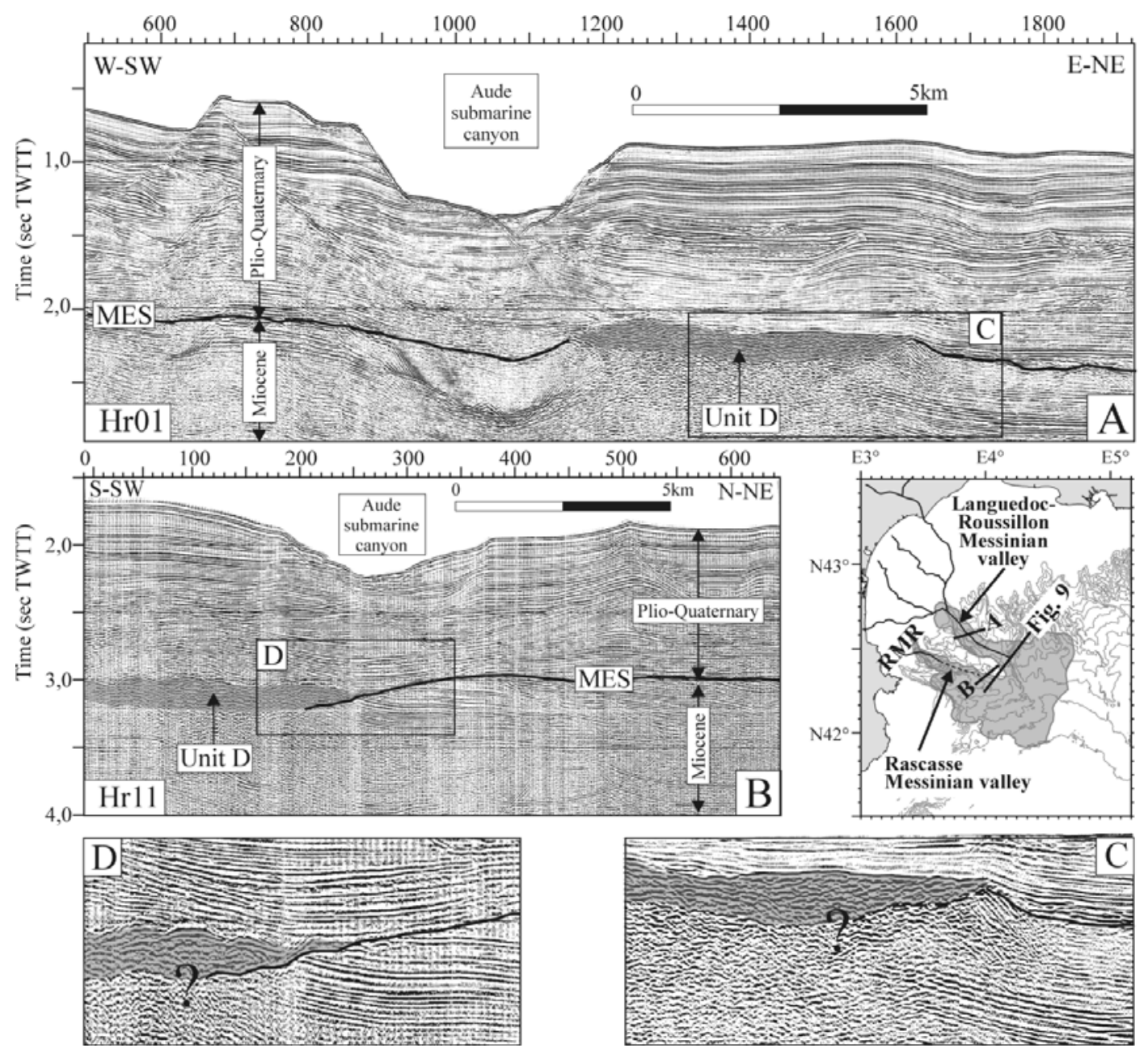

Fig. 8 - Strike seismic profiles HR01 (A) and HR11 (B) across the present-day upper and middle slope, locally illustrating the presence of a chaotic seismic unit (Unit D) at the base of the Plio-Quaternary sequence. C, D: zooms on Unit D. MES: Messinian Erosional Surface. RMR: Rascasse Miocene paleo-Rollover. 

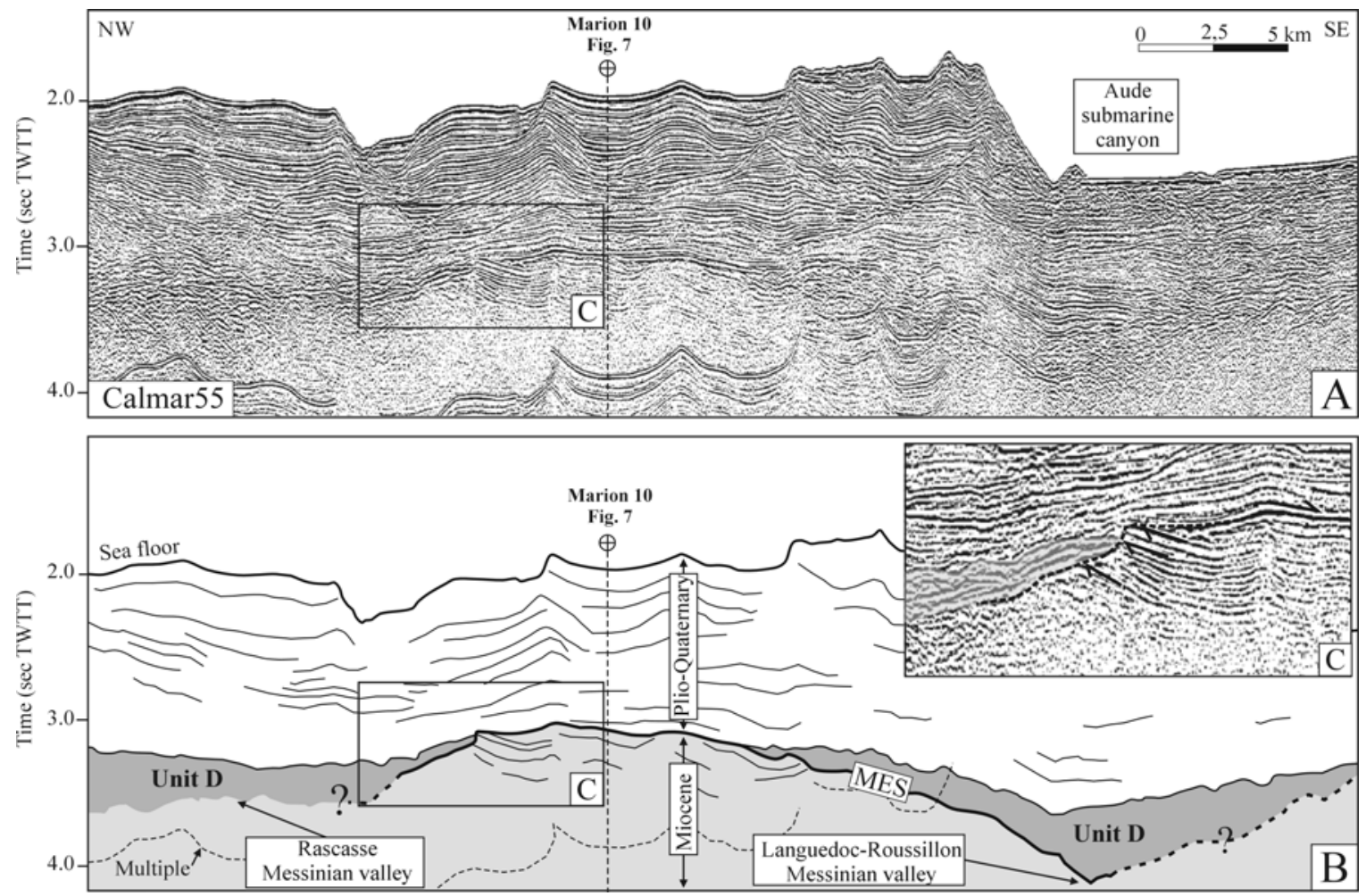

Fig. 9 - Uninterpreted (A) and interpreted (B) Calmar 55 strike seismic profile across the present-day middle slope. A chaotic seismic unit (Unit D) at the base of the Plio-Quaternary sequence has accumulated along the axis of the Messinian lows. This unit is interpreted as Messinian detrital deposits. See Figs. 1 and 8 for profile location. C: zoom on the sharp contact between Unit D and the Miocene truncated lateral reflectors.
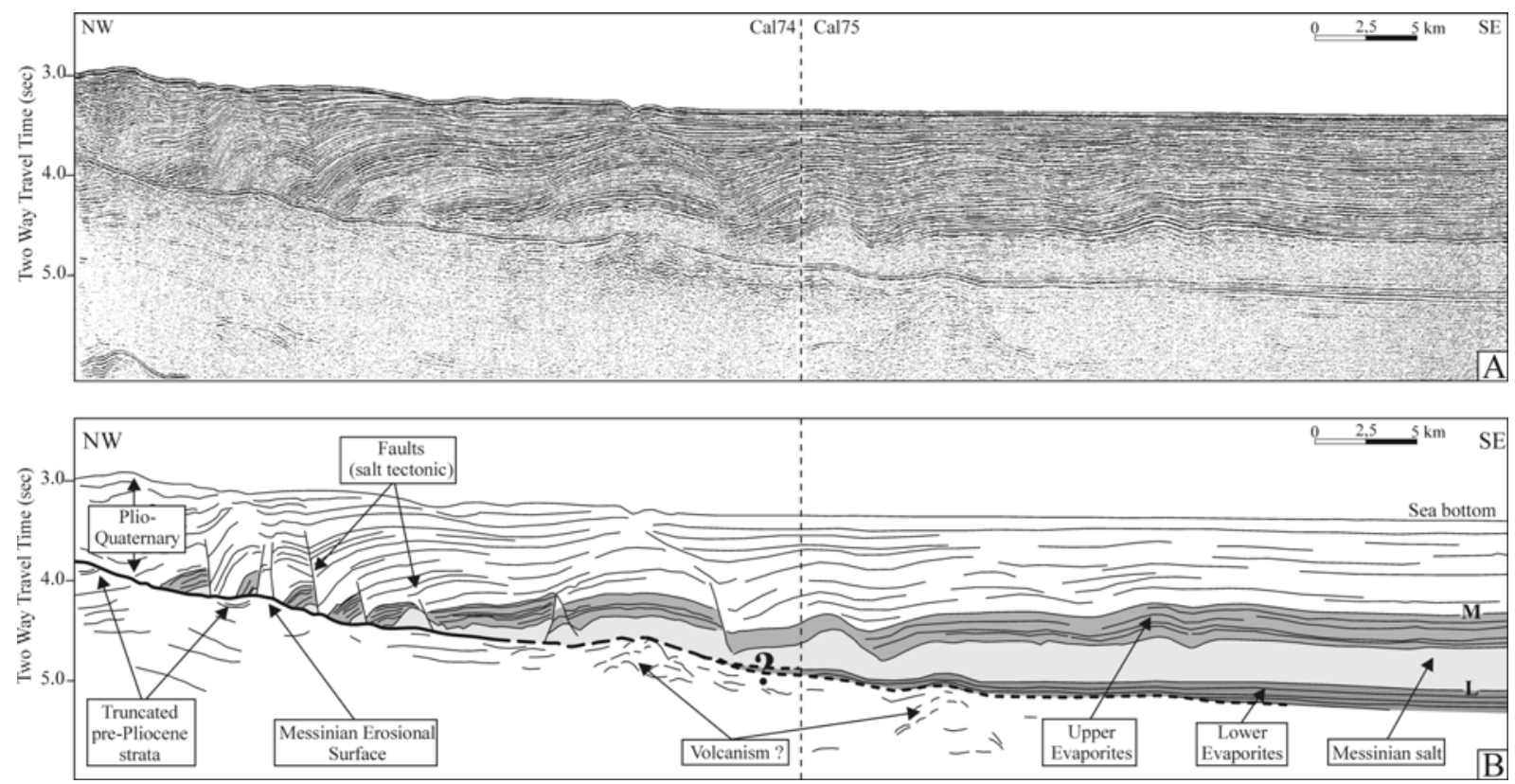

Fig. 10 - Uninterpreted (A) and interpreted (B) Calmar 74-75 dip seismic reflection profile showing the pinchout of the Salt and Upper Evaporite units against the Messinian Erosional Surface (MES) beneath the lower continental slope,. The MES continues out under the Salt layer and possibly correlates laterally with the base of the Lower Evaporites. L: reflector from Biju-Duval et al. (1978). See Fig. 1 for profile location. 


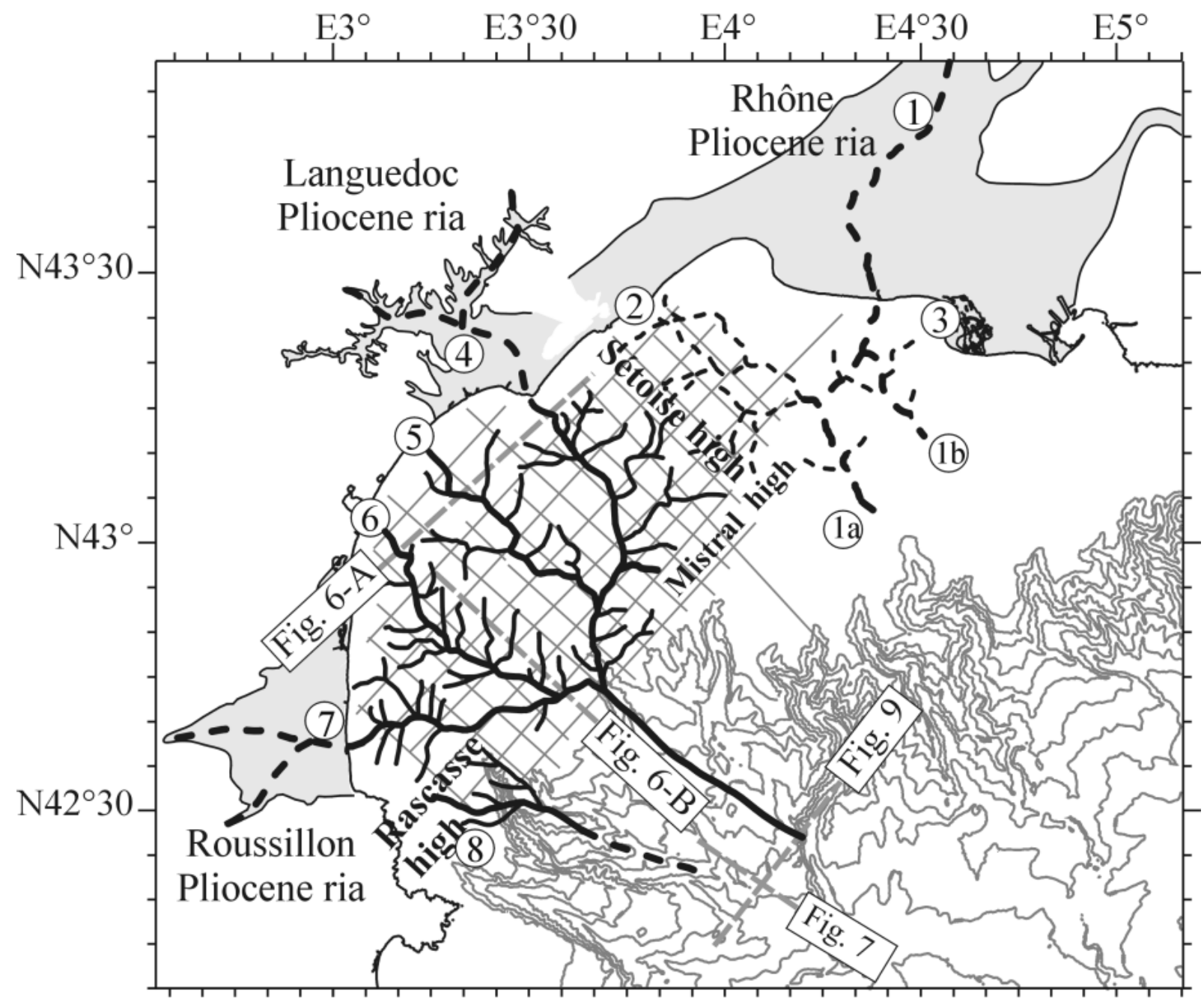

\begin{tabular}{|l|ll|}
\hline Languedoc-Roussillon paleo-network & Rhone paleo-network \\
\hline \begin{tabular}{llll|} 
(8) Rascasse (6) La Berre (4) Orb-Hérault & (3) Beauduc & (1) Rhône \\
(7) Têt-Tech & (5) Proto Aude & (2) Vidourle & \\
\hline
\end{tabular}
\end{tabular}

Fig. 11 - Map of the Messinian fluvial networks in the Gulf of Lions. In the western part, the LanguedocRoussillon network consists of four distinct river patterns that coalesce beneath the outer shelf. The Rascasse network is located in the south-western extremity of the outer shelf, on the southern flank of the Rascasse Miocene rollover. Grey areas correspond to onshore Pliocene rias. The Berre and proto-Aude are entirely downcut beneath the present-day shelf. 


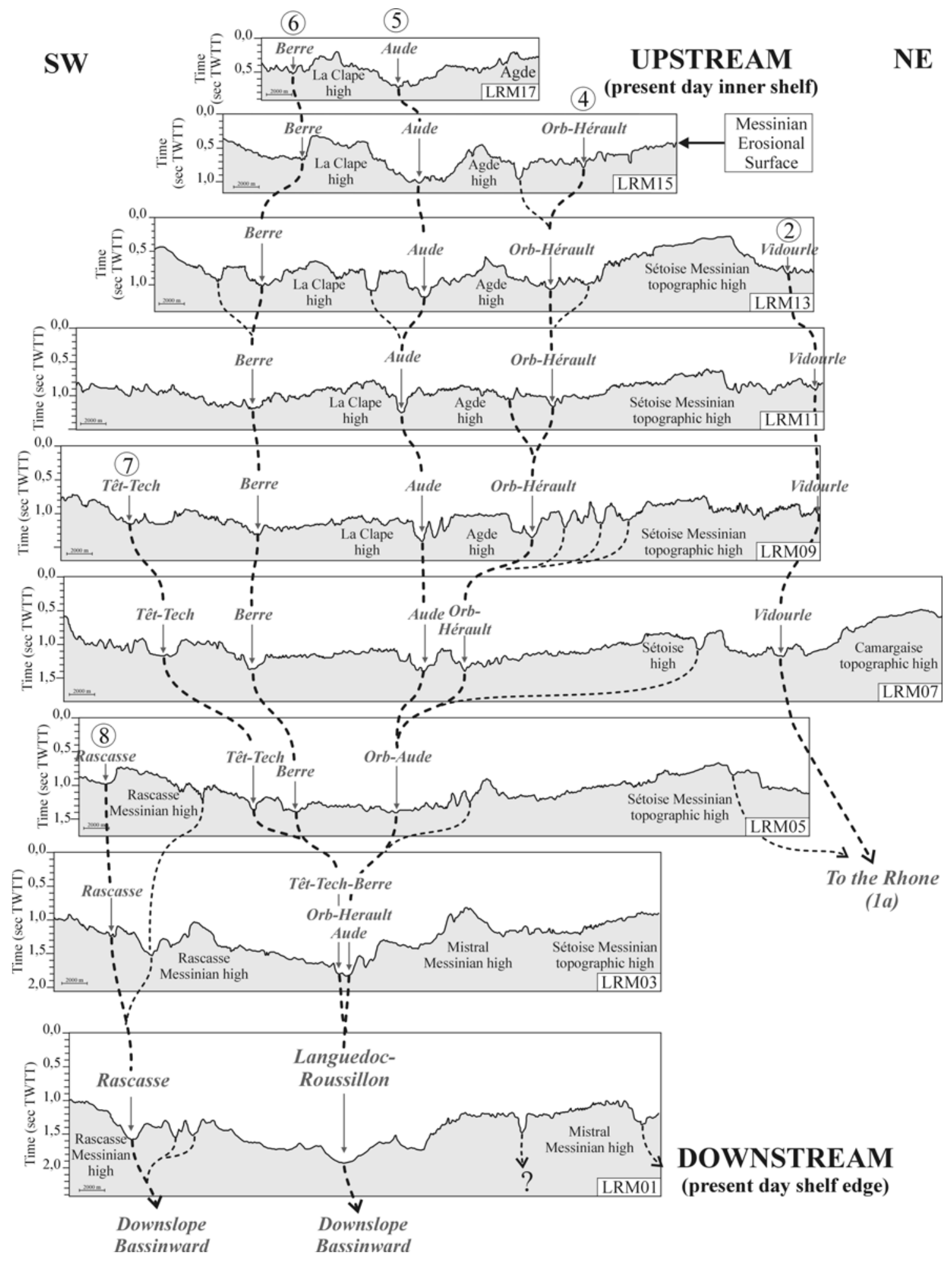

Fig. 12 - Line drawings of the Messinian Erosional Surface (LRM profiles), illustrating the upstreamdownstream morphological changes in the Languedoc-Roussillon valleys. See Fig. 1 for profile locations. 

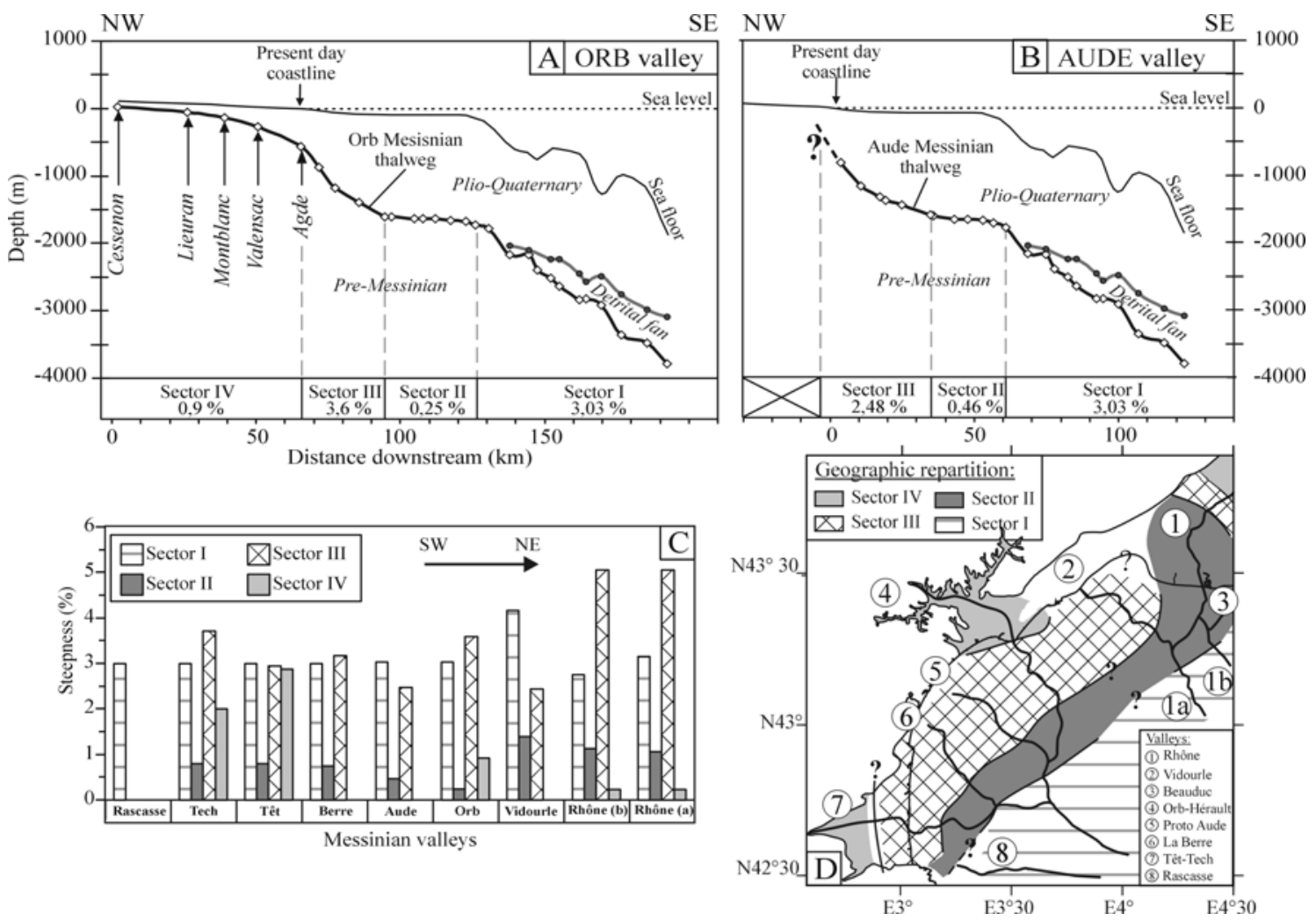

Fig. 13 - Present-day longitudinal profiles of the Orb (A) and Aude (B) Messinian valleys respectively displaying flat-steep-flat-steep and steep-flat-steep sequences. These sequences are labelled sectors I to IV in an upstream direction. C: diagram illustrating the alternation of steep and flat sectors along the Messinian valleys of the Gulf of Lions. D: geographic layout of fluvial sectors I to IV over the margin. 

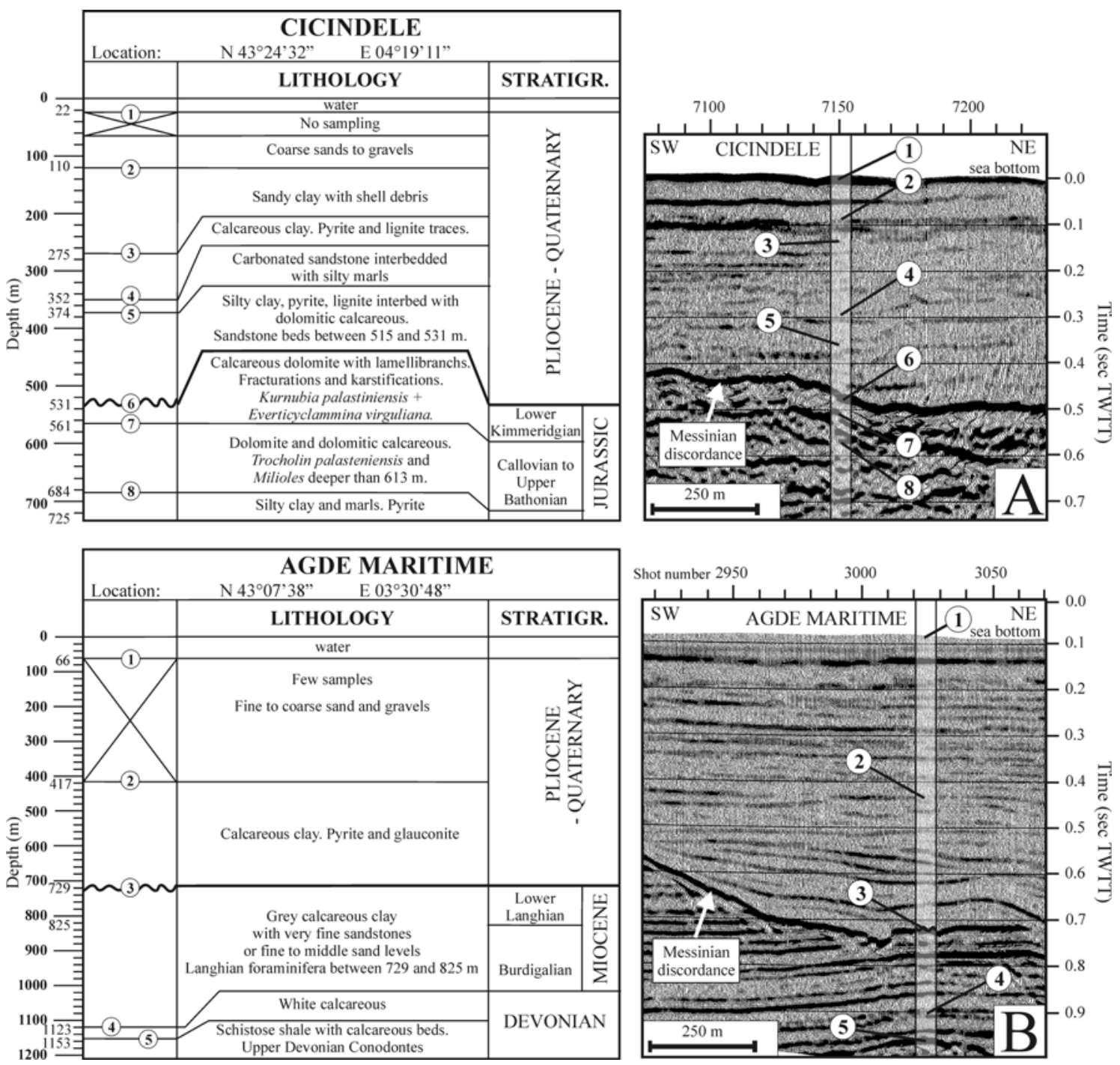

Fig. 14 - Stratigraphic correlation between the seismic lines and the Cicindèle (A) and Agde Maritime (B) exploratory wells (see Fig. 1 for locations). Borehole descriptions are from the drilling reports. The Messinian unconformity is distinct and easily correlated with the seismic data. 

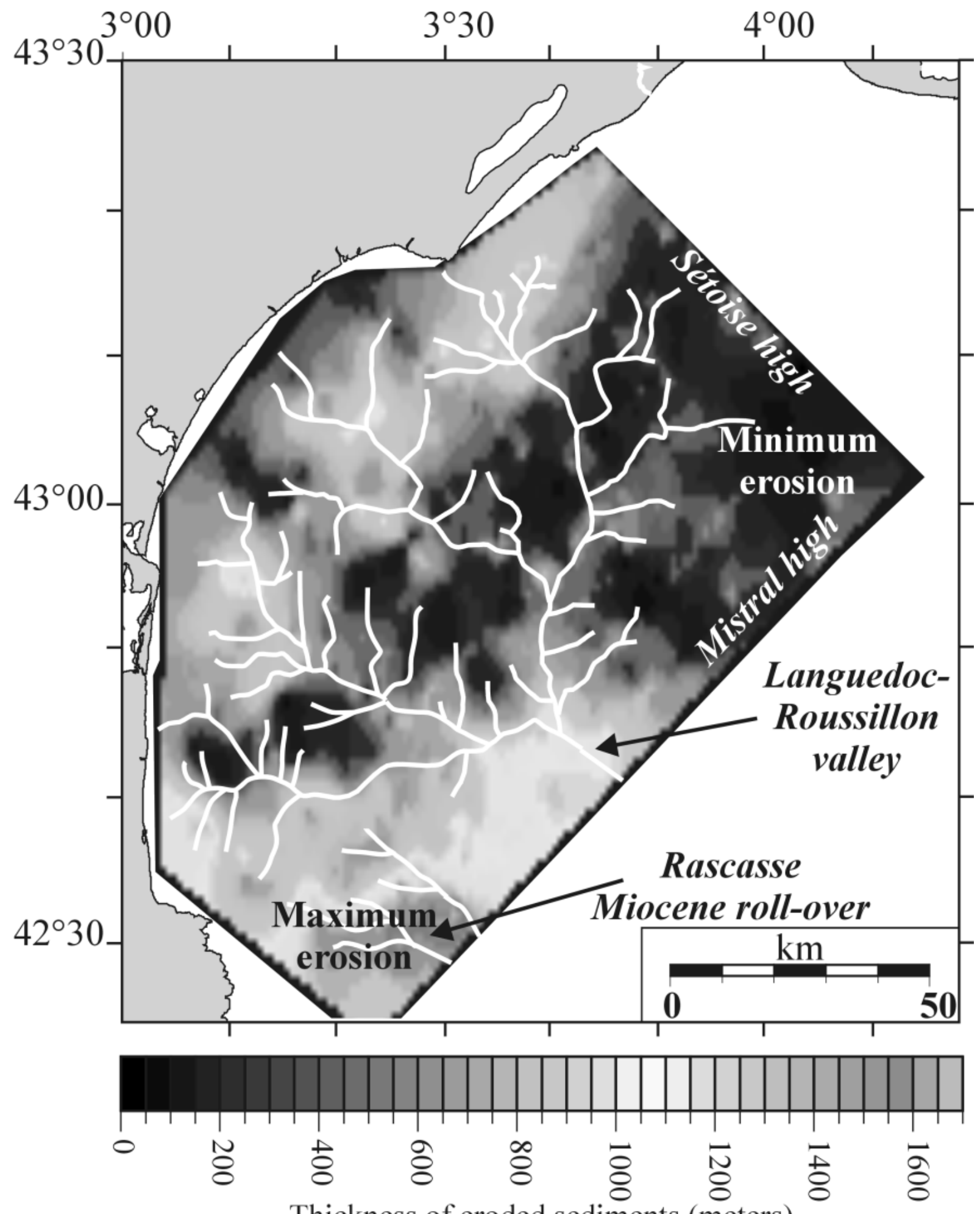

Fig. 15 - Isopach map of the estimated eroded volume from the Miocene shelf during the Messinian Salinity Crisis. Maximum erosion corresponds to the river axis and to the Rascasse Miocene rollover. Minimum erosion is observed beneath the inner shelf, close to the coastline and in the Sétoise high area. 

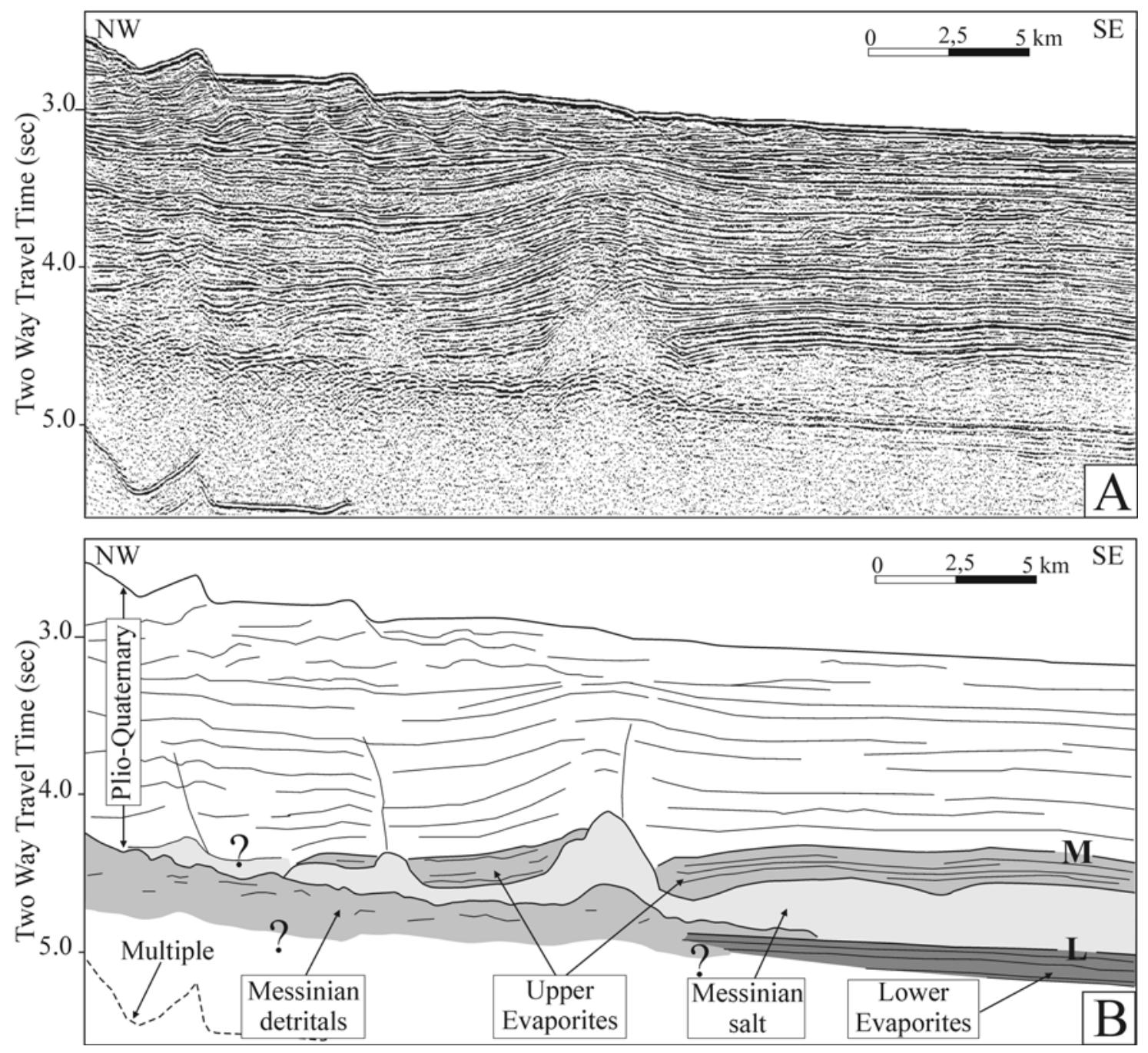

Fig. 16 - Uninterpreted (A) and interpreted (B) Calmar 66 seismic profile in the Gulf of Lions showing, beneath the lower continental slope, the presence of the chaotic seismic Unit D extending below the Salt and Upper Evaporites. The distal part of this unit may partly correlate with the Lower Evaporite unit. See Fig. 1 for profile location. 


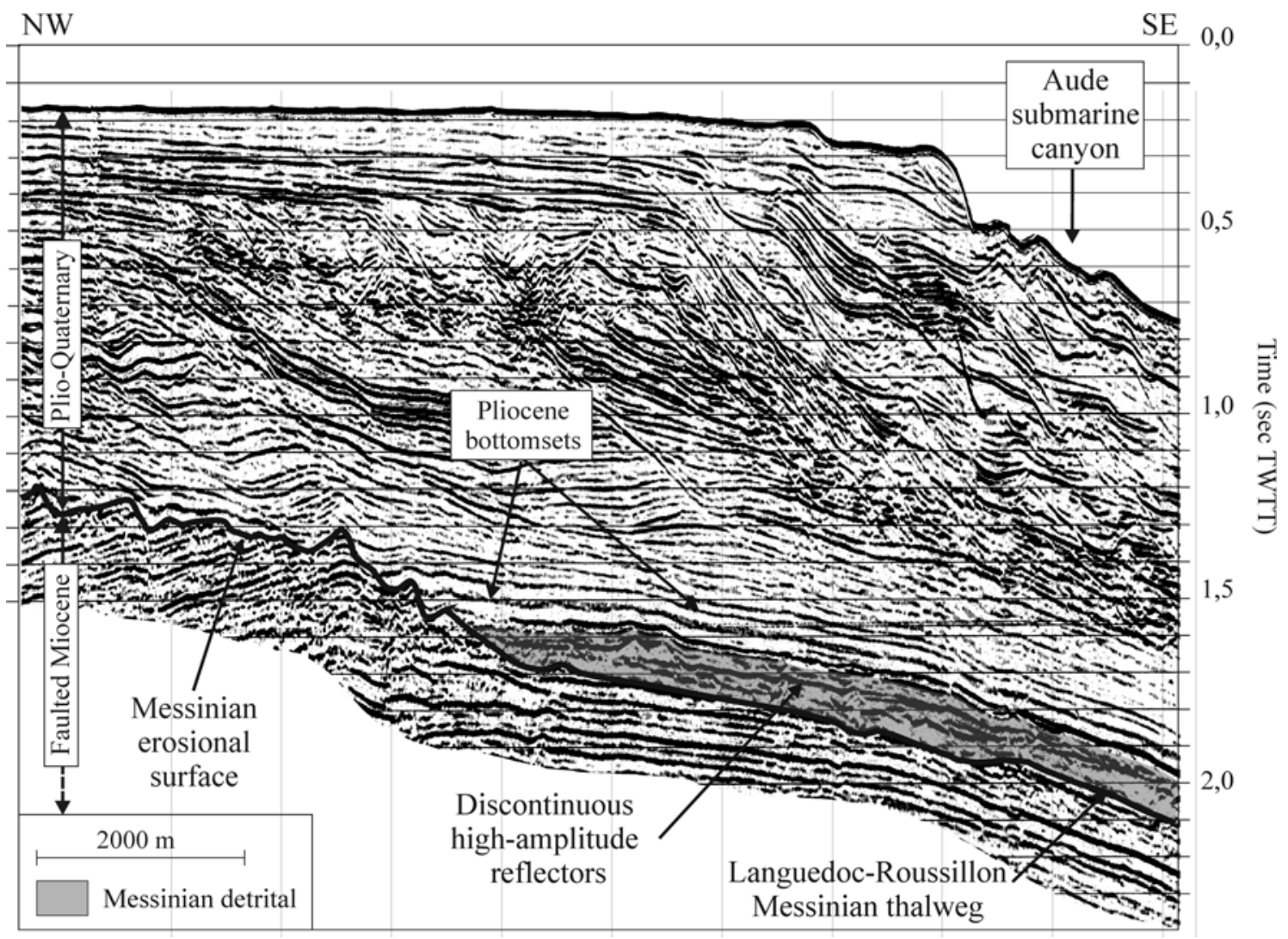

Fig. 17 - LRM14 dip seismic line section beneath the outer shelf. Discontinuous high-amplitude reflectors above the Messinian Erosional Surface are interpreted as the landward continuation of Unit D, overlain by draped Pliocene bottomsets. See Fig. 1 for profile location. 


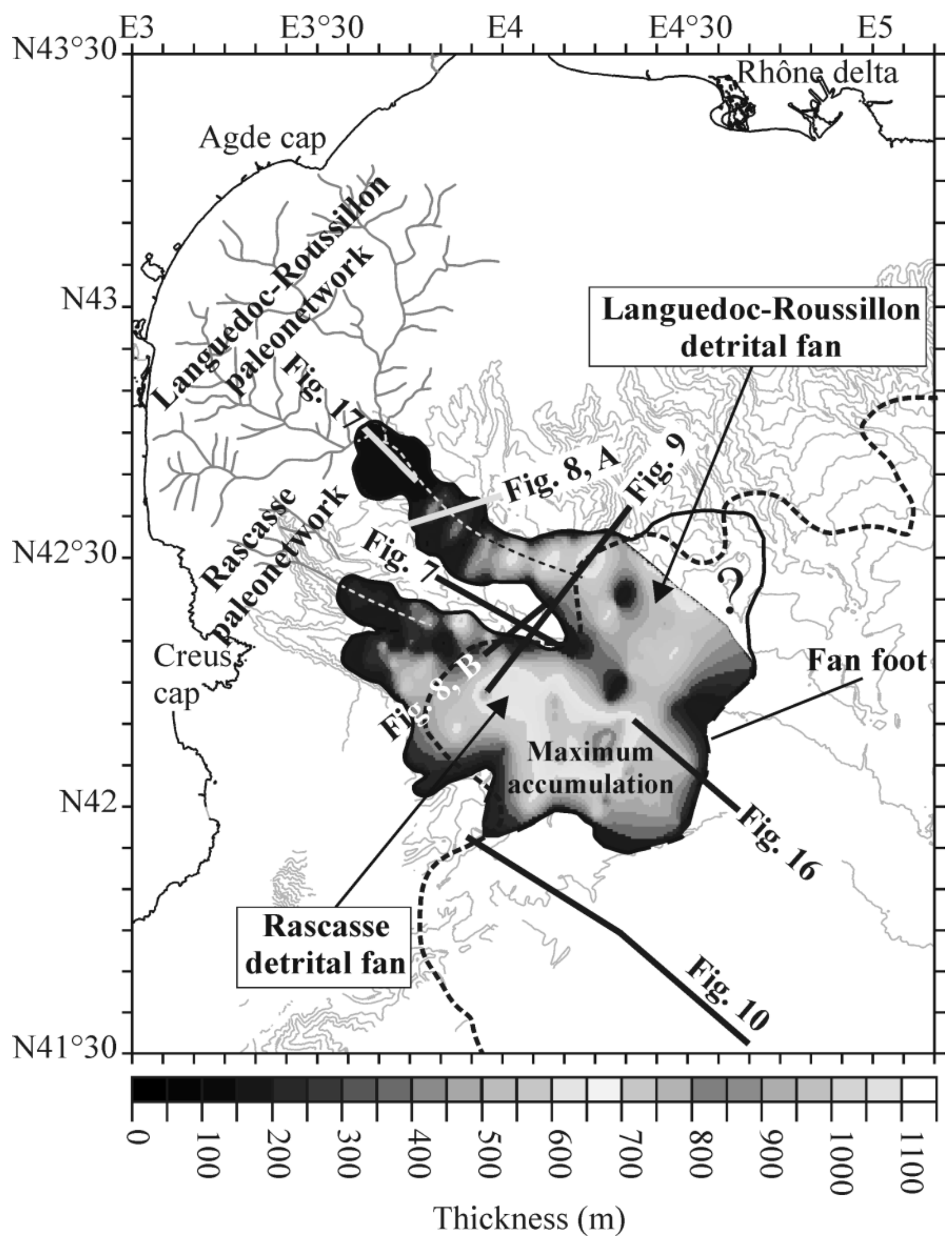

Fig. 18 - Isopach map of the Messinian detrital fans beneath the slope. Maximum accumulation is located in the Rascasse fan. Dashed bold line: onlap of the Messinian Salt in the basin (after Dos Reis, 2001). 


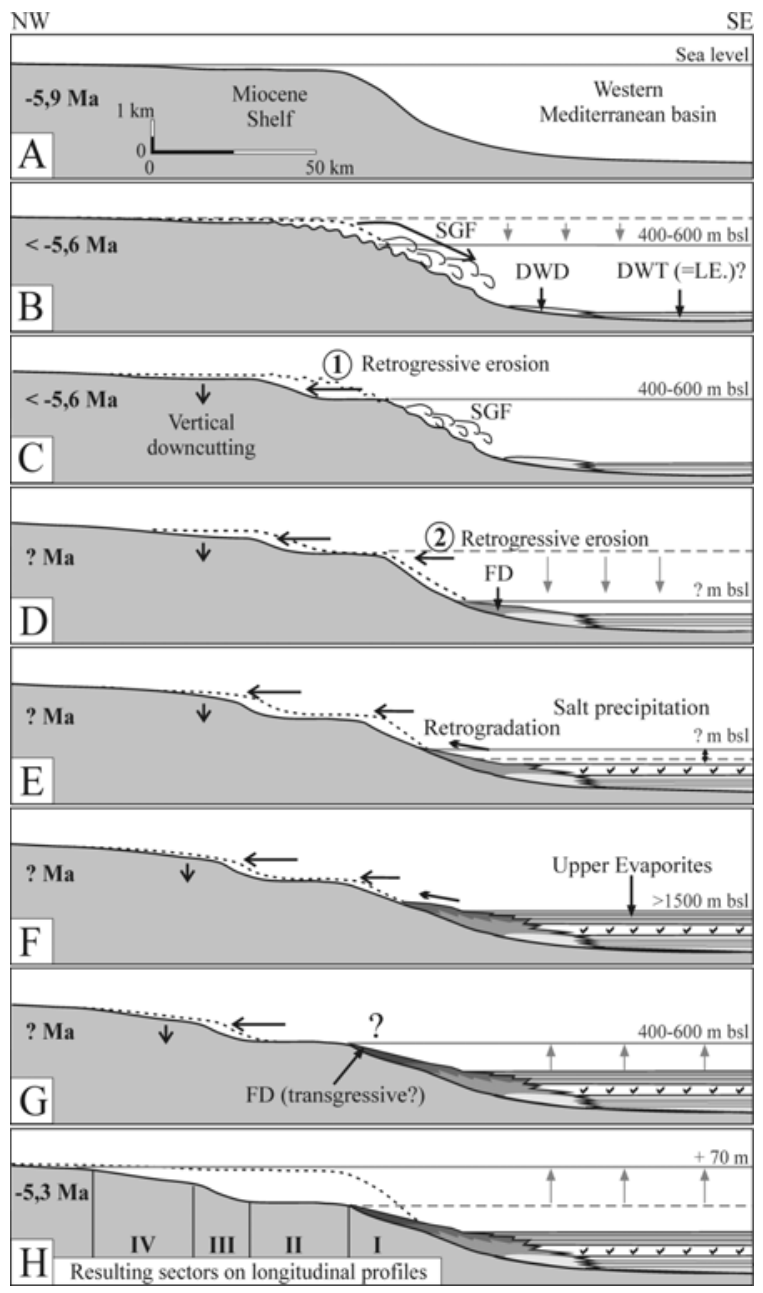

Fig. 19 - Sketch illustrating the construction of the Messinian detrital fans and how the (flat)-steep-flat-steep longitudinal profiles of the Messinian rivers could be the result of eustatic changes. The scenario involves a temporary base-level stillstand during the sea-level fall.

A: Miocene shelf before the crisis.

B: Lowering of the sea-level triggers slope instabilities on the outer shelf and upper slope, and massive basinward sediment transfer. Erosion is dominated by slope instabilities and gravity processes. Accumulation of the distal part of the detrital fan downslope, and of a part of the Lower Evaporites (interpreted as deep-water clastic deposits in this case) in the basin.

C: Temporary base level. Rivers incise the shelf to adjust their base-level to the lowered sea level. Initiation of the first phase of retrogressive erosion. Erosion by submarine gravity flows on the slope and deposition of the distal fan and Lower Evaporites.

D: Second sea-level fall. Rivers incise the formerly submerged continental slope. Initiation of the second phase of retrogressive erosion. Erosion and sedimentation are dominated by fluvial processes.

E: Precipitation of the thick Salt layer in the basin provoking retrogradation of the detrital deposits and filling of the Messinian valleys. Salt onlaps the earlier detrital deposits. The height of the water column in the basin before and after Salt precipitation remains a matter of speculation.

F: Deposition of the Upper Evaporites in a basin considered, in this case, as almost totally desiccated. Retrogradation of the detrital deposits in the Messinian valleys. Upper Evaporites onlap the previously deposited detrital deposits. The onlap limit marks the position of the coastline.

G: Refilling of the Mediterranean Basin at the end of the crisis. Deposition of the landward part of the detrital fan during the final transgression?

$\mathrm{H}$ : End of the Messinian Salinity Crisis. Establishment of a flat-steep-flat-steep longitudinal profile of the Messinian rivers after the refilling of the Mediterranean basin.

SGF: submarine gravity flows; DWD: deep-water detrital deposits; DWT: deep-water turbidites; L.E.: Lower Evaporites; FD: fluvial deposits. 